\title{
A Systematic Review of Orthosiphon stamineus Benth. in the Treatment of Diabetes and Its Complications
}

\author{
Qirou Wang ${ }^{1}$, Jia Wang ${ }^{1}$, Nannan $\mathrm{Li}^{1}{ }^{1}$, Junyu Liu ${ }^{1}$, Jingna Zhou ${ }^{1}$, Pengwei Zhuang ${ }^{2}$ and Haixia Chen ${ }^{1, *(D)}$ \\ 1 Tianjin Key Laboratory for Modern Drug Delivery \& High-Efficiency, School of Pharmaceutical Science \\ and Technology, Tianjin University, Tianjin 300072, China; wangqirou110@163.com (Q.W.); \\ jiawangcongcong@163.com (J.W.); 13234039725@163.com (N.L.); junyuliu@tju.edu.cn (J.L.); \\ jingnazhou66@163.com (J.Z.) \\ 2 Haihe Laboratory of Modern Chinese Medicine, Chinese Materia Medica College, Tianjin University of \\ Traditional Chinese Medicine, Tianjin 301617, China; zhuangpengwei@163.com \\ * Correspondence: chenhx@tju.edu.cn; Tel.: +86-22-2740-1483
}

Citation: Wang, Q.; Wang, J.; Li, N.; Liu, J.; Zhou, J.; Zhuang, P.; Chen, H. A Systematic Review of Orthosiphon stamineus Benth. in the Treatment of Diabetes and Its Complications. Molecules 2022, 27, 444. https:// doi.org/10.3390/molecules27020444 Academic Editors: Weishuo Fang and Yu Zhang

Received: 11 December 2021

Accepted: 5 January 2022

Published: 10 January 2022

Publisher's Note: MDPI stays neutral with regard to jurisdictional claims in published maps and institutional affiliations.

Copyright: (C) 2022 by the authors. Licensee MDPI, Basel, Switzerland. This article is an open access article distributed under the terms and conditions of the Creative Commons Attribution (CC BY) license (https:// creativecommons.org/licenses/by/ $4.0 /)$.

\begin{abstract}
Background: Orthosiphon stamineus Benth. is a traditional medicine used in the treatment of diabetes and chronic renal failure in southern China, Malaysia, and Thailand. Diabetes is a chronic metabolic disease and the number of diabetic patients in the world is increasing. This review aimed to systematically review the effects of $O$. stamineus in the treatment of diabetes and its complications and the pharmacodynamic material basis. (2) Methods: This systematic review was conducted following Preferred Reporting Items for Systematic Reviews and Meta-Analyses (PRISMA), using the databases ScienceDirect, PubMed, and Web of Science. (3) Results: Thirty-one articles related to O. stamineus and diabetes were included. The mechanisms of $O$. stamineus in the treatment of diabetes and its complications mainly included inhibiting $\alpha$-amylase and $\alpha$-glucosidase activities, antioxidant and anti-inflammatory activities, regulating lipid metabolism, promoting insulin secretion, ameliorating insulin resistance, increasing glucose uptake, promoting glycolysis, inhibiting gluconeogenesis, promoting glucagon-likepeptide-1 (GLP-1) secretion and antiglycation activity. Phenolic acids, flavonoids and triterpenoids might be the main components for hypoglycemia effects in $O$. stamineus. (4) Conclusion: $O$. stamineus could be an antidiabetic agent to treat diabetes and its complications. However, it needs further study on a pharmacodynamic substance basis and the mechanisms of effective constituents.
\end{abstract}

Keywords: Orthosiphon stamineus; diabetes; diabetic complications; hypoglycemic activity; antidiabetic mechanisms

\section{Introduction}

Orthosiphon stamineus Benth. (Lamiaceae) is a perennial herb [1,2]. O. stamineus is widely distributed in the tropical and subtropical regions [3], including southeast Asian countries (Indonesia, Malaysia, Thailand, Vietnam, Myanmar, Philippines) [4,5], southern China [6], India [7], Australia [5], etc. In addition to Orthosiphon stamineus Benth., it also has other scientific names, Clerodendranthus spicatus (Thunb) c. y. wu and Orthosiphon aristatus (Blume) Miq. [8-10]. It is usually called "Shencha" in Chinese. It is also called Cat's whiskers [11], Misai Kucing [12], Java tea [13], and kumis kucing [14] in some Southeast Asian countries.

O. stamineus is a popular Chinese folk medicine and also a traditional medicine of Dai nationality of Yunnan Province in China [15]. It has been used to treat diabetes and some kidney diseases with a long history. Modern pharmacological studies show that O. stamineus has many pharmacological activities, including antioxidant, anti-inflammatory, kidney protection, antibacterial, anti-tumor, immunoregulation, and especially effective antidiabetic activities. $[15,16]$. It has been used for the treatment of diabetes and chronic renal failure clinically. It is also reported to have good therapeutic effects on some diabetic 
complications, especially diabetic nephropathy [6]. Thus, it is worthy of study for the discovery for new antidiabetic drugs from O. stamineus.

Diabetes is a chronic metabolic diseases caused by deficiency in insulin secretion and insulin resistance [17]. In 2021, diabetic patients were estimated to be approximately 537 million all over the world [18]. This number is on the rise, the reasons for which are an aging population, obesity, and unhealthy diets [19]. Diabetes can be classified into two major types: Type I Diabetes Mellitus (T1DM) and Type II Diabetes Mellitus (T2DM). T1DM is caused by insulin deficiency. The islet $\beta$-cells are damaged, leading to an absolute deficiency of insulin secretion. Patients need long-term exogenous insulin injection. However, for T2DM patients, metabolic disorder results in lower insulin sensitivity, insulin resistance, and relative insulin deficiency [17,19-21]. DM can damage organs and tissues and result in many complications, such as diabetic nephropathy, diabetic retinopathy, diabetic foot, diabetic neuropathy, etc.

Diabetes is treated with oral hypoglycemic drugs and insulin injection to reduce blood glucose levels, improve insulin secretion, and enhance insulin sensitivity. Besides, there also are natural products used in the treatment of diabetes, especially with good hypoglycemic effects. In classical antidiabetic drugs, exenatide is from the venom of Gila monster and acarbose is produced from Actinoplanes sp. by the large-scale fermentation [22,23]. Besides, metformin is a natural product derivative that originated from herbal medicine Galega officinalis and its constituent galegine [24]. Many other natural products, such as curcumin, cinnamon, pumpkin, bitter melon, Lycium barbarum, Portulaca oleracea, Aloe vera, etc., have also been proven to have antidiabetic activities but without general clinical practice $[20,21,25-27]$. Orthosiphon stamineus also has potential against diabetes.

More than 200 compounds have been isolated from O. stamineus. Diterpenoids, flavonoids, triterpenoids, phenolic acids, and their derivatives are the main chemical constituents. There are almost 50 phenolic acids and their derivatives isolated from $O$. stamineus, including rosmarinic acid, caffeic acid, and their derivatives, and many others [6,28]. More than 20 flavonoids have been isolated from O. stamineus. Most of them are flavones, especially polymethoxy substituted flavones [29]. Besides, more than 60 diterpenoids have been isolated up to now and they have various skeleton types, including isopimarane [30], staminane [31], secoisopimarane [30], norstaminane [31], secostaminane, and some other types. Besides, there are also almost 20 triterpenoids isolated from O. stamineus $[5,32,33]$. In addition to the above four main types, there are also other kinds of compounds isolated from O. stamineus, such as two alkyl glycosides (clerspides A and B) [34], coumarins, etc. Many of the compounds studied have acted as the main pharmacodynamic material basis of O. stamineus in the treatment of diabetes and its complications.

In a review by Omar Z. Ameer, the traditional uses, phytochemical studies, pharmacological studies, and toxicology were summarized. In Kamran Ashraf's review, only phytochemical studies and pharmacological studies until 2018 were summarized. The pharmacological activities of $O$. stamineus mentioned in the two reviews included antiinflammatory, antioxidant, diuretic, hypouricemic, hepatoprotective, gastroprotective, nephroprotective, analgesic, antipyretic, cytotoxic, antiproliferative, antihypertensive, hypoglycemic, hypolipidemic, anti-obesity, and antibacterial activities [35,36]. In Yin-Sir Chung's review, the protective actions of $O$. stamineus on the central nervous system, safety and toxicity, and pharmacokinetics studies were summarized [8]. Although there are many studies on the potential of $O$. stamineus in the treatment of diabetes and its complications, no article has reviewed the antidiabetic mechanisms and pharmacodynamic material basis of $O$. stamineus in detail.

In this systematic review, the mechanisms and toxicology of O. stamineus in the treatment of diabetes and its complications were summarized as per Preferred Reporting Items for Systematic Reviews and Meta-Analyses (PRISMA) [37,38]. PRISMA provides guidance for authors to prepare transparent, complete, and accurate systematic reviews. Research progress on clinical applications and the main pharmacodynamic material basis 
of $O$. stamineus was reviewed, providing a reference for the application of $O$. stamineus and further research in the treatment of diabetes and its complications.

\section{Results}

\subsection{Literature Search Results}

After searching in the three databases by using the chosen keywords, a total of 281 studies were obtained. Of the 281 records, 181 were from ScienceDirect, 35 from PubMed, and 65 from Web of Science. Then, 153 records were removed for the following reasons: duplicate studies, reviews, book chapters, patents, meeting papers, and non-English language papers. By reviewing the titles and abstracts, 88 records were excluded because they had no relevance to the scope of this review. The remaining 40 records were read fully, and 31 were included in this systematic review. The flowchart of the literature search and selection process is shown in Figure 1 and the 31 articles are summarized in Table 1.

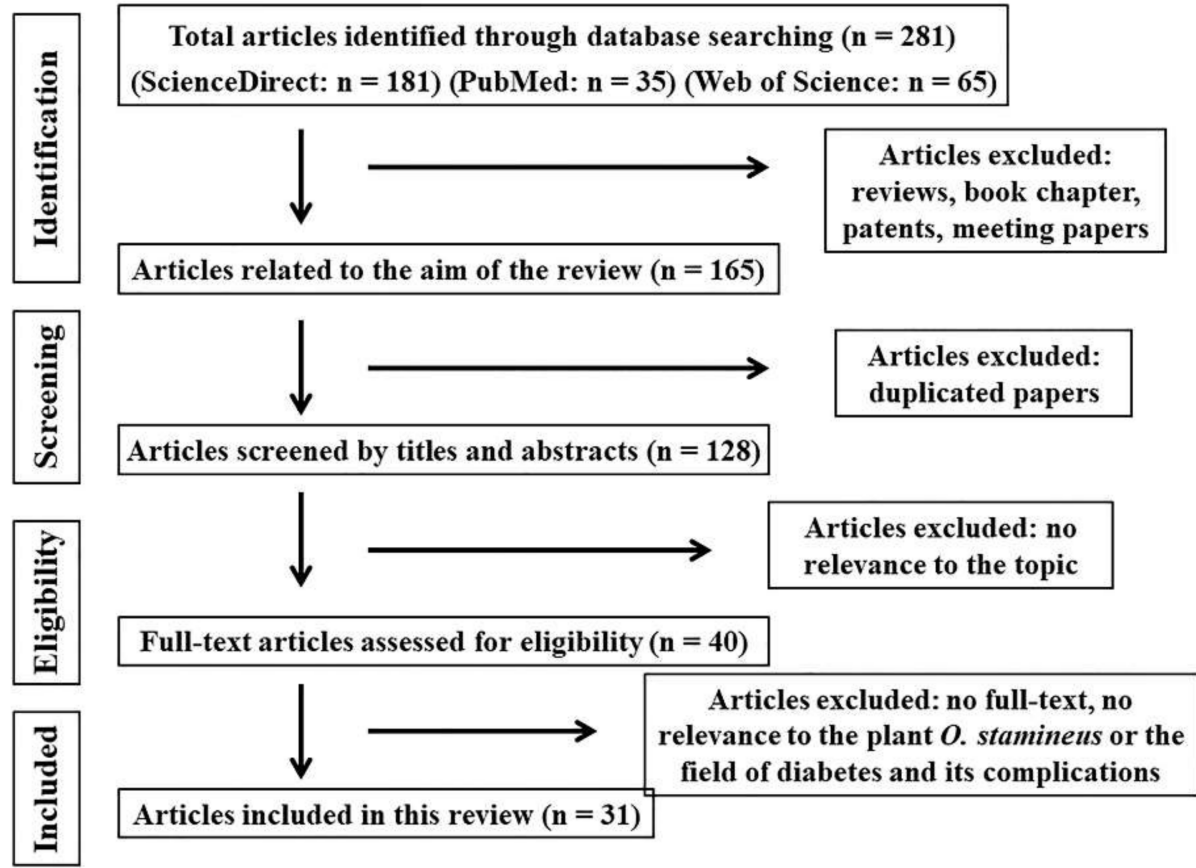

Figure 1. The flowchart of the literature search and selection process based on PRISMA.

\subsection{Hypoglycemic Activity}

Hyperglycemia is a main symptom of diabetes, and could cause damage to organs and tissues in the body. It has been proved in some studies that different extracts of O. stamineus could decrease blood glucose levels.

In a recent study, the $95 \%$ ethanol elution fraction (95\% EEF) of $80 \%$ ethanol extract $(0.68 \mathrm{~g} / \mathrm{kg}, 0.34 \mathrm{~g} / \mathrm{kg}$ and $0.17 \mathrm{~g} / \mathrm{kg})$ reduced blood glucose levels in an oral glucose tolerance test in normal C57BL/6J mice after 10-day administration of the extract [39]. The ethanol extract of $O$. stamineus $(0.2$ and $0.4 \mathrm{~g} / \mathrm{kg})$ obviously reduced fasting blood glucose level in high-fat-diet (HFD) C57BL/6 mice after 8-week administration of the extract [40]. The rats were administered 50\% ethanol extract orally and after ten minutes, they were loaded with starch or sucrose. The extract $(1 \mathrm{~g} / \mathrm{kg})$ reduced blood glucose levels significantly after starch loading in both normal and diabetic rats. The same dose of the extract also lowered blood glucose levels significantly after sucrose loading in normal rats [41]. The rats were administered chloroform extract and its sub-fraction $2(1 \mathrm{~g} / \mathrm{kg})$ orally and after one hour, they were loaded subcutaneously with glucose. The extract and its sub-fraction 2 significantly reduced the blood glucose levels of normal rats [42]. The same sub-fraction $(1 \mathrm{~g} / \mathrm{kg})$ also caused a significant decrease in blood glucose levels in diabetic rats after 14-day administration of the sub-fraction [34]. The normal and diabetic 
rats were administered the aqueous extract orally and after ten minutes, they were loaded with glucose. In normal rats, the aqueous extract $(0.5 \mathrm{~g} / \mathrm{kg}$ and $1.0 \mathrm{~g} / \mathrm{kg})$ reduced plasma glucose concentration by $15 \%$ and $34 \%$, respectively, after one hour of glucose loading. The maximum reduction of the extract $(0.5 \mathrm{~g} / \mathrm{kg}$ and $1.0 \mathrm{~g} / \mathrm{kg})$ on diabetic rats was $21 \%$ and $24 \%$ after $210 \mathrm{~min}$ of glucose loading. Besides, the diabetic rats were also treated with the extract $(0.5 \mathrm{~g} / \mathrm{kg})$ for 14 days and showed reduction in plasma glucose concentration [43].

\subsection{Mechanisms of O. stamineus in the Treatment of Diabetes \\ 2.3.1. Antioxidant Activity}

Hyperglycemia metabolism and excessive free fatty acids can lead to the production of lots of free radicals, such as reactive oxygen species (ROS) and reactive nitrogen species (RNS). These free radicals can cause oxidative stress, impair the structures and functions of islet $\beta$-cells, and cause insulin secretion deficiency. Besides, they can also lead to insulin resistance by affecting multiple insulin signaling pathways. The antioxidant activity of $O$. stamineus is related to protecting islet cells and reducing insulin resistance. Researchers have always tested antioxidant activity by 1,1-diphenyl-2-picrylhydrazyl radical 2,2-diphenyl-1-(2,4,6-trinitrophenyl)hydrazyl (DPPH) assay, ferric ion reducing antioxidant power (FRAP) assay, and 2,2'-azino-bis-(3-ethylbenzothiazoline-6-sulphonate) (ABTS) assay. The activity of superoxide dismutase (SOD) and the level of malondialdehyde (MDA) are also used to determine antioxidant activities. SOD can scavenge free radicals and MDA is the end product of lipid oxidation [44,45].

The antioxidant properties of the ethanol extracts of some genotypes ranged up to $15.55 \mu \mathrm{mol}$ trolox equivalent (TE)/g dry weight (DW) in DPPH assay, and ranged up to $1.60 \mathrm{mmol} \mathrm{TE} / \mathrm{g}$ DW in FRAP assay [46]. The half maximal inhibitory concentration (IC50) value of the $70 \%$ ethanol extract was $58.85 \pm 7.11 \mu \mathrm{g} / \mathrm{mL}$ in DPPH assay, a little higher than $15.05 \pm 2.03 \mu \mathrm{g} / \mathrm{mL}$ of the positive control, rosmarinic acid [47]. The concentration value for $50 \%$ of maximal effect (EC50) of methanol extract was $0.67 \mathrm{mg} / \mathrm{mL}$ in DPPH assay [48]. The IC50 values of 50\% methanol extract of $O$. stamineus leaves were $0.145 \pm 0.030$, $1.143 \pm 0.056,0.192 \pm 0.012$, and $0.013 \pm 0.001 \mathrm{mg} / \mathrm{mL}$ in DPPH, ABTS, iron chelating and FRAP assays, respectively, a little higher than the positive control, rutin and caffeic acid [49]. The EC50 values of $O$. stamineus aqueous extract were 53.51 and $284.9 \mu \mathrm{g} / \mathrm{mL}$, respectively, in DPPH and ABTS assays, higher than the positive control, ascorbic acid [50]. The antioxidant capacities of aqueous extract were higher than $20 \mathrm{mg}$ ascorbic acid equivalents (VCEAC)/100 mL in ABTS assays, and about $40 \mathrm{mg}$ VCEAC/100 $\mathrm{mL}$ in FRAP assays [51]. The DPPH free radical-scavenging activities of aqueous, 50\% methanol, methanol, 70\% acetone, and chloroform extracts $(0.05 \mathrm{mg} / \mathrm{mL})$ were about $85 \%, 90 \%, 88 \%, 83 \%$ and $70 \%$, respectively, higher than some positive controls [52].

From these studies, it could be seen that the aqueous extract, ethanol extract, $70 \%$ ethanol extract, methanol extract, 50\% methanol extract, 70\% acetone extract, and chloroform extract all had free radical-scavenging activities in different assays.

O. stamineus ethanol extract (200 and $400 \mathrm{mg} / \mathrm{kg}$ ) enhanced SOD activity and reduced MDA level in the liver homogenate of the high-fat diet group. Thus, O. stamineus extract might counteract oxidative stress in the liver [40]. The $50 \%$ ethanol extracts of 0 . stamineus roots, stems, and leaves $(50 \mu \mathrm{g} / \mathrm{mL})$ scavenged intracellular ROS and significantly increased cell viability under oxidative stress in IPEC-J2 cells. They could also decrease the MDA level in jejunal homogenates compared to the high-fat group. The extracts of roots and leaves significantly increased the jejunal SOD activity of mice [53].

\subsubsection{Anti-Inflammatory Activity}

In the pathogenesis of diabetes, inflammatory factors, such as interleukin (IL)- $1 \beta$, IL-8, tumor necrosis factor (TNF)- $\alpha$, and induced nitric oxide synthase (iNOS), are important factors related to insulin sensitivity. They interfere with insulin signal transduction by participating in the insulin signaling pathway, leading to insulin resistance. They also possibly damage islet $\beta$-cells. In addition, inflammatory factors also interact with oxidative 
stress, further aggravating insulin resistance. Therefore, anti-inflammatory activity is essential to attenuate the inflammatory response, protect islet cells, and improve insulin resistance. It is always tested through the levels of inflammatory factors and the inhibition of nitric oxide (NO) production in cells $[54,55]$.

The swelling in auricle was inhibited by the treatment of ethanol extract, ethyl acetate (EtOAc), and aqueous fractions in acute inflammatory mice induced by xylene. The inhibition ratios were $48.2 \%, 63.3 \%$, and $46.0 \%$ at the dose of $200 \mathrm{mg} / \mathrm{kg}$. Some compounds isolated from EtOAc fractions, orthosiphol $\mathrm{M}$, orthosiphonone A, orthosiphol B, neoorthosiphol A, orthosiphol D, fragransin $\mathrm{B}_{1}$, sinensetin and 5, 6, 7, 4' -tetramethoxyflavone, also showed marked repression in the observed auricle swelling at the dose of $50 \mathrm{mg} / \mathrm{kg}$. Besides, some of these compounds inhibited pro-inflammatory cytokines production in lipopolysaccharide (LPS)-induced HK-2 cells, such as the levels of TNF- $\alpha$, IL-1 $\beta$, and IL-8 [56]. The isolated compounds (clerodens A-D) were studied for anti-inflammatory activities on LPS-induced NO production in RAW264.7 macrophages. The results showed that clerodens A-D had inhibitory activities with IC50 values of $18.9 \pm 1.2,14.7 \pm 0.48$, $12.4 \pm 1.5$, and $6.8 \pm 0.92 \mu \mathrm{mol} / \mathrm{L}$, respectively, a little higher than the positive control aminoguanidine [16]. Neoorthosiphonone A, isolated from O. stamineus, showed obvious inhibitory activity on NO production in LPS-activated macrophage-like J774.1 cells with the IC50 value of $7.08 \mu \mathrm{mol} / \mathrm{L}$, which was more potent than the positive control $\mathrm{N}^{\mathrm{G}}$-monomethyl-L-arginine (L-NMMA) [57]. The isolated siphonols A-E also inhibited NO production in LPS-activated macrophage-like J774.1 cells [58].

\subsubsection{Regulate Lipid Metabolism}

Diabetic patients often have abnormal lipid metabolism. In the pathogenesis of diabetes, disorders in lipid metabolism increase the levels of free fatty acids and total triglycerides (TG), damaging islet $\beta$-cells and leading to insulin resistance in other tissue cells. Because of insulin resistance, the serum levels of TG, total cholesterol (TC), and low-density lipoprotein cholesterol (LDL-C) increase, while the level of high-density lipoprotein cholesterol (HDL-C) decreases [59]. In addition, leptin and adiponectin, which are secreted from adipocytes, are also associated with insulin resistance. Leptin can antagonize insulin and produce insulin resistance, while adiponectin can improve insulin sensitivity by increasing fatty acid oxidation and glucose uptake in skeletal muscle cells [60,61].

The inhibitory effect of $O$. stamineus ethanol extract against pancreatic lipase in vitro was determined by using orlistat as the positive control. The IC50 value of the extract was $5.7 \mathrm{mg} / \mathrm{mL}$, compared to the value of orlistat $(0.1 \mathrm{mg} / \mathrm{mL})$. In vivo study, the mice were fed on HFD. The ethanol extract reduced the serum levels of TG, TC, LDL-C, and lipase. It also decreased the leptin level and increased the adiponectin level. The extract also attenuated excessive accumulation of fat in liver tissues through histological examination. These results all showed that the extract might regulate lipid metabolisms in adipocytes, downregulate lipid accumulation in the liver [40]. The aqueous extract lowered TC level and increased the ghrelin level in diabetic rats [62]. The aqueous extract also lowered TG level and increased HDL-C level in diabetic rats [43]. 3-Hydroxybutyrate (3-HBT) and acetoacetate were the representative metabolites of fatty acid metabolism, so their levels might be related to the lipid metabolism in the liver. In ${ }^{1} \mathrm{H}-\mathrm{NMR}$ spectroscopic analysis of urine of Azam' study, aqueous extract showed a remarkable drop in acetoacetate and 3-HBT levels. The reason for that might be that the extract inhibited the abnormal lipid and fatty acid metabolism and re-established energy metabolism [63].

\subsubsection{Inhibit the Activities of $\alpha$-Amylase and $\alpha$-Glucosidase}

$\alpha$-Amylase and $\alpha$-glucosidase are the two key enzymes in the digestion and absorption of carbohydrates in the body. $\alpha$-Amylase breaks down long-chain carbohydrates, and $\alpha$ glucosidase hydrolyzes glucoside bonds to release glucose. They are directly involved in the metabolism of starch and glycogen. Therefore, inhibiting the activities of $\alpha$-amylase and $\alpha$-glucosidase can reduce the release of glucose from carbohydrate hydrolysis, slow 
down the absorption of glucose in the small intestine, and effectively lower postprandial blood glucose level $[44,64,65]$. The inhibitory activities of these enzymes were always tested in vitro.

Rosmarinic acid and 2-caffeoyl-L-tartaric acid were two constituents isolated from O. stamineus. In a recent study, their inhibition ratios on $\alpha$-glucosidase $(0.5 \mathrm{U} / \mathrm{mL})$ were $71.06 \pm 1.82 \%$ and $69.85 \pm 1.27 \%$, respectively, both higher than that of positive control, acarbose, at concentration of $5 \mathrm{mg} / \mathrm{mL}$. Molecular docking results showed that the binding energy of 2-caffeoyl-L-tartaric acid and $\alpha$-glucosidase was $-7.7 \mathrm{kcal} / \mathrm{mol}$, and there were 3 hydrogen bonds between them. The binding energy of rosmarinic acid and $\alpha$-glucosidase was $-8.6 \mathrm{kcal} / \mathrm{mol}$. In the conformation of $\alpha$-glucosidase-rosmarinic acid complex, there were 6 hydrogen bonds [66]. The 95\% EEF showed higher $\alpha$-glucosidase $(86 \mu \mathrm{g} / \mathrm{mL})$ inhibitory activity $(\mathrm{IC50}=40 \pm 0.73 \mu \mathrm{g} / \mathrm{mL})$ than acarbose $(\mathrm{IC5} 0=250 \pm 1.05 \mu \mathrm{g} / \mathrm{mL})$ [39] The ethanol extract $(1000 \mu \mathrm{g} / \mathrm{mL})$ of some genotypes of $O$. stamineus inhibited $\alpha$-glucosidase up to $62.84 \%$ [46]. The ethanol extract at concentration of $50 \mu \mathrm{g} / \mathrm{mL}$ inhibited $\alpha$-glucosidase $(0.57 \mathrm{U} / \mathrm{mL})$ at $40.74 \%, \alpha$-amylase $(1.6 \mathrm{U} / \mathrm{mL})$ at $81.48 \%$, higher than acarbose[67]. The $50 \%$ ethanol extract and the isolated compound sinensetin both showed inhibitory activity on $\alpha$-glucosidase and $\alpha$-amylase. The IC50 values on $\alpha$-glucosidase $(1.0 \mathrm{U} / \mathrm{mL})$ were $4.63 \pm 0.413$ and $0.66 \pm 0.025 \mathrm{mg} / \mathrm{mL}$, and on $\alpha$-amylase $(0.5 \mathrm{mg} / \mathrm{mL})$ were $36.70 \pm 0.546$ and $1.13 \pm 0.026 \mathrm{mg} / \mathrm{mL}$, respectively. The IC50 values of acarbose on $\alpha$-glucosidase and $\alpha$-amylase were $1.93 \pm 0.281 \mathrm{mg} / \mathrm{mL}$ and $4.89 \pm 0.397 \mathrm{mg} / \mathrm{mL}$, respectively [68].

\subsubsection{Promote Insulin Secretion, Ameliorate Insulin Resistance, Enhance Insulin Sensitivity}

Insulin is a hormone secreted by islet $\beta$-cells. It can control blood glucose level and regulate glucose and lipid metabolism. Insulin promotes glucose uptake and utilization in the liver, muscle, and adipose cells to reduce postprandial blood glucose level. However, these functions can be achieved only by combining with insulin receptors (IR). IRs are widely distributed in the body. Muscle, fat, and liver are all insulin target organs or tissues. Insulin resistance occurs when insulin receptors become less sensitive to insulin due to various factors [69]. Normally, glucose is transported and utilized mainly under the stimulation of insulin through a variety of insulin signaling pathways, such as the phosphoinositide 3-kinase/protein kinase B (PI3k/Akt) pathway. Insulin binds to IRs on the cell membrane, causing tyrosine phosphorylation of insulin receptor substrates (IRS), activating the PI3k/Akt signaling pathway and increasing glucose uptake. Any abnormality in insulin signaling pathway may lead to insulin resistance [70,71]. In addition, protein tyrosine phosphatase 1B (PTP1B) is also associated with insulin resistance. High PTP1B activity can lead to the dephosphorylation of IR and IRS tyrosine and weaken insulin signal transduction, leading to insulin resistance [72,73]. In some investigations, it has been proved that the extract of $O$. stamineus and its active components promoted insulin secretion, improved insulin resistance, and enhanced insulin sensitivity.

Inhibition of PTP1B activity might improve IR and IRS, leading to the improvement of insulin resistance and enhancement of insulin sensitivity. Hence, five diterpenes isolated from $O$. stamineus were tested for PTP1B inhibitory activity. The IC50 values of siphonol B, orthosiphols B, G, I, and N were 8.18 $\pm 0.41,9.84 \pm 0.33,3.82 \pm 0.20$, $0.33 \pm 0.07$, and $1.60 \pm 0.17 \mu \mathrm{mol} / \mathrm{L}$, respectively, compared to the positive control, ursolic acid $(3.42 \pm 0.26 \mu \mathrm{mol} / \mathrm{L})$. The inhibition types of these five diterpenes on PTP1B were mixed-competitive, non-competitive, non-competitive, competitive, and uncompetitive, respectively [74]. The hexane fraction of $70 \%$ ethanol extract slightly increased insulin secretion in both basal and glucose-stimulated states, and also elevated the mRNA expression of insulin and pancreatic duodenal homeobox-1 (PDX-1) in INS-1 cells under normal and high-glucose conditions. PDX-1 is an essential transcription factor for insulin gene expression. Its main functions are to promote the proliferation of islet $\beta$-cells, inhibit the apoptosis of islet $\beta$-cells, and regulate the transcription of insulin genes. The fraction also increased p-PI3K levels and Akt phosphorylation in INS-1 cells [75]. The ethanol extract 
reduced the levels of homeostasis model assessment of insulin resistance (HOMA-IR) index in HFD-induced rats [40].

From these studies, it could be seen that the hexane fraction of $70 \%$ ethanol extract could promote insulin secretion and enhance insulin sensitivity. Besides, the ethanol extract and five diterpenes isolated from $O$. stamineus could both enhance insulin sensitivity.

\subsubsection{Reduce the Absorption of Intestinal Glucose, Increase Glucose Uptake by} Peripheral Cells

Hyperglycemia is a typical characteristic of diabetes. Carbohydrates are absorbed by intestinal epithelial cells in the form of glucose after digestion by enzymes. The uptake and utilization of glucose mainly exist in peripheral tissues or cells, such as liver, muscle, and adipose cells. Therefore, reducing the absorption of intestinal glucose and promoting glucose uptake by peripheral cells are very important to reduce blood glucose [76].

The sub-fraction 2 of chloroform extract significantly inhibited the glucose absorption from the small intestine at concentrations of $0.5,1.0$, and $2.0 \mathrm{mg} / \mathrm{mL}$. Sub-fraction 2 $(2.0 \mathrm{mg} / \mathrm{mL})$ significantly increased the glucose uptake of hemi-diaphragms during the 90-min incubation period [34]. Some diterpenes in O. stamineus had 2-deoxy-2-((7-nitro2,1,3-benzoxadiazol-4-yl)amino)-D-glucose (2-NBDG) uptake effect in 3T3-L1 adipocytes. 2-NBDG was always used as a substrate to evaluate the action of compounds as insulin mimickers. Siphonol B, orthosiphols B, G, I, and N stimulated glucose uptake at the concentration of 5 and $10 \mu \mathrm{mol} / \mathrm{L}$ [74]. The aqueous extract of $O$. stamineus significantly enhanced glucose uptake and glucose consumption in 3T3-L1 adipocytes [77]. The O. stamineus aqueous extract could increase the glucose uptake in cells by measuring the traces of radiolabelled glucose in 3T3-L1 adipocytes model [78].

\subsubsection{Promote Glycolysis, Inhibit Gluconeogenesis}

Gluconeogenesis and glycolysis are two metabolic mechanisms to ensure glucose homeostasis. Glycolysis is the process of breaking down glucose to produce pyruvate, which is one of the most important pathways of glucose metabolism in the body. Increasing the expression of glucokinase and pyruvate kinase can promote glycolysis and reduce blood glucose. Gluconeogenesis is the process of converting non-sugar substances into glucose. Liver is the main organ for gluconeogenesis. Both insulin and glucagon can regulate liver gluconeogenesis through different signaling pathways $[79,80]$.

In ${ }^{1} \mathrm{H}-\mathrm{NMR}$ spectroscopic analysis of urine of diabetic rats, aqueous extract increased the levels of pyruvate, succinate, and citrate compared to the model group. Pyruvate is an end product of glycolysis, and it can enter tricarboxylic acid (TCA) cycle. High glucose level inhibits glycolytic enzymes and decreases the generation of pyruvate, thereby reducing the TCA cycle activity, and thus may contribute to mitochondrial dysfunction. Mitochondrial dysfunction may induce diabetes by affecting insulin secretion of islet $\beta$-cells and aggravating insulin resistance. Citrate and succinate are the TCA cycle intermediates. Thus, the increased levels of pyruvate, citrate, and succinate showed that the aqueous extract might reduce blood glucose level by increasing glycolysis and decreasing gluconeogenesis, and it might also modulate TCA cycle and improve mitochondrial dysfunction [63].

\subsubsection{Increase the Level of GLP-1}

GLP-1 is released from intestinal cells and maintains blood glucose homeostasis by increasing insulin secretion and inhibiting glucagon secretion [81]. The aqueous extract of O. stamineus $(0.1 \mathrm{~g} / 100 \mathrm{~g}$ of body weight) increased GLP-1 level in diabetic rats-nonpregnant or pregnant [62].

\subsection{Mechanisms of O. stamineus in the Treatment of Diabetic Complications}

Chronic hyperglycemia may cause damage to vessels and microvessels, and also damage tissues and organs in the body, leading to diabetic nephropathy, diabetic retinopathy, diabetic foot, diabetic peripheral neuropathy, and diabetic cardiovascular complications. 
These diabetic complications are related to oxidative stress, nonenzymatic glycation of protein, and inflammatory factors [82].

In addition to antioxidant and anti-inflammatory activity, O. stamineus also has antiglycation effects. The glycation process is the formation of Amadori products at first through the chemical reactions between amino acid residues in proteins and reducing sugars. These products transform into advanced glycation end products (AGEs) by dehydration and rearrangement reactions. The accumulation of AGEs is toxic to cells and tissues, leading to diabetic complications. The aqueous extract of $O$. stamineus had inhibitory capacities (more than 70\%) on the formation of AGEs in bovine serum albumin (BSA)-glucose system [51].

Diabetic nephropathy $(\mathrm{DN})$ is one of the main complications of diabetes. It may lead to renal failure. The $O$. stamineus aqueous extract lowered the $24 \mathrm{~h}$ urine albumin excretion rate (UAER), glomerular filtration rate (GFR), the index of kidney weight to body weight and MDA level in kidney tissues of diabetic rats. It also improved the activity of SOD in renal tissues. Under a light microscope, $O$. stamineus obviously improved the lesions of renal tissues. The protective effect of $O$. stamineus on diabetic rats may be related to antioxidative activity, anti-inflammatory activity, and inhibition of the proliferation of mesangial cells [83].

\subsection{Toxicity}

Even though most traditional herbal medicines are generally recognized as safe, they also need to be evaluated the safety and toxicity. Toxicology studies have led to a better understanding of human physiology and drug interactions with the body.

There was no cytotoxicity effect of $O$. stamineus aqueous extract on 1.1B4, 3T3-L1, and WRL-68 cells viability during $24 \mathrm{~h}$ treatment at a concentration of $1.0 \mathrm{mg} / \mathrm{mL}$. In fish embryo acute toxicity (FET) test on zebrafish, there was also no mortality on zebrafish embryos at $1.0 \mathrm{mg} / \mathrm{mL}$ [50].

Several studies were about the possible toxicity of O. stamineus in rats. In an acute toxicity study, the aqueous, 50\% ethanol and ethanol extracts of $O$. stamineus $(5000 \mathrm{mg} / \mathrm{kg}$ ) were administered orally to rats for 14 days. In other acute studies, methanol extract and $50 \%$ ethanol extract were also administered to rats. While in the subchronic toxicity study, the $50 \%$ ethanol extract was administered orally at doses of 1250,2500 , and $5000 \mathrm{mg} / \mathrm{kg}$ for 28 days. There was no mortality or any signs of toxicity during the experiment periods. There was also no significant difference in body weight, organ weights, haematological parameters, and microscopic appearance of the organs from the treatment groups. Thus, the extract with these doses would not cause any acute or subchronic toxicity and organ damages in rats. The oral median lethal dose $\left(\mathrm{LD}_{50}\right)$ might be more than $5000 \mathrm{mg} / \mathrm{kg}$ body weight [84-86].

The O. stamineus aqueous extract $(0,250,500,1000$, and $2000 \mathrm{mg} / \mathrm{kg} /$ day $)$ did not change pregnancy body weight gain, food and water consumption, and caused no other sign of maternal toxicity in pregnant rats on gestation days 6-20. There was no embryo lethality and prenatal growth retardation either [87].

The genotoxicity of O. stamineus aqueous extract was evaluated by the Salmonella/ microsome mutation assay and the mouse bone marrow micronucleus test. The result showed that $O$. stamineus extract was not toxic to Salmonella strains and did not have any potential to induce gene mutations in Salmonella strains. The aqueous extract was also not toxic to the mouse bone marrow. Thus, the use of $O$. stamineus aqueous extract had no genotoxic risk [88]. 
Table 1. Summary of articles reported for antidiabetic effects and toxicity of $O$. stamineus.

\begin{tabular}{|c|c|c|c|}
\hline No. & Tested Substances & Study Design and Protocol & Ref. \\
\hline 1 & 2-Caffeoyl-L-tartaric acid, rosmarinic acid & $\alpha$-Glucosidase inhibitory activity and molecular docking & [66] \\
\hline 2 & $95 \%$ EEF of $80 \%$ ethanol extract & $\begin{array}{l}\text { Oral glucose tolerance test in normal C57BL/6J mice } \\
\alpha \text {-Glucosidase inhibitory activity }\end{array}$ & [39] \\
\hline 3 & Ethanol extract & $\alpha$-Glucosidase and $\alpha$-amylase inhibitory activity & [46] \\
\hline 4 & $\begin{array}{l}\text { Ethanol extract, aqueous and EtOAc fractions of } \\
\text { ethanol extract, } 25 \text { compounds isolated from EtOAc } \\
\text { fraction }\end{array}$ & $\begin{array}{l}\text { Measurement of pro-inflammation cytokine } \\
\text { in vitro } \\
\text { Xylene-induced acute inflammatory model of mice }\end{array}$ & [56] \\
\hline 5 & Ethanol extract & $\begin{array}{l}\alpha \text {-Glucosidase inhibitory activity } \\
\text { Antioxidant activity (DPPH and FRAP assays) }\end{array}$ & [46] \\
\hline 6 & Siphonol B, orthosiphols B, G, I and N & $\begin{array}{l}\text { Measurement of 2-NBDG uptake in 3T3-L1 adipocytes } \\
\text { PTP1B inhibitory activity }\end{array}$ & [74] \\
\hline 7 & Aqueous extract & $\begin{array}{l}\text { Oral glucose tolerance test } \\
\text { Plasma analysis (insulin, cholesterol, GLP-1, and ghrelin } \\
\text { levels) in diabetic rats }\end{array}$ & [62] \\
\hline 8 & $70 \%$ Ethanol extract and 9 fractions & Antioxidant activity (DPPH assay) & {$[47]$} \\
\hline 9 & $50 \%$ Methanol extract & $\begin{array}{l}\text { Antioxidant activity (DPPH, ABTS, iron chelating and } \\
\text { FRAP assays) }\end{array}$ & [49] \\
\hline 10 & Ethanol extract & $\begin{array}{l}\text { Pancreatic lipase inhibitory activity in vitro } \\
\text { Biochemical serum analysis (TG, TC, LDL, lipase, and } \\
\text { glucose levels) in HFD-induced rats } \\
\text { Measurement of leptin, adiponectin, insulin, and } \\
\text { HOMA-IR index in HFD-induced rats } \\
\text { Determination of antioxidant activity in liver tissue in } \\
\text { HFD-induced rats } \\
\text { Histological assessment of liver tissues in } \\
\text { HFD-induced rats }\end{array}$ & [40] \\
\hline 11 & Aqueous extract & $\begin{array}{l}\text { Antioxidant activity (DPPH and ABTS assays) } \\
\text { Cytotoxicity assay, embryotoxicity assay }\end{array}$ & {$[50]$} \\
\hline 12 & Aqueous extract & ${ }^{1} \mathrm{H}-\mathrm{NMR}$ spectroscopic analysis of urine of diabetic rats & [63] \\
\hline 13 & Aqueous, $50 \%$ ethanol and ethanol extracts & Acute toxicity study in rats & [84] \\
\hline 14 & Clerodens A-D & $\begin{array}{l}\text { Assay for inhibitory ability against LPS-induced NO } \\
\text { production in RAW264.7 macrophages }\end{array}$ & [16] \\
\hline 15 & $50 \%$ Ethanol extract & $\begin{array}{l}\text { Oral carbohydrate challenge tests in normal and diabetic } \\
\text { rats (respectively starch, surcose, and glucose loading) }\end{array}$ & [41] \\
\hline 16 & Hexane fraction of $70 \%$ ethanol extract & $\begin{array}{l}\text { Glucose stimulated insulin secretion test } \\
\text { Real time-polymerase chain reaction }\end{array}$ & [75] \\
\hline 17 & Aqueous extract & Effects on glucose uptake & [78] \\
\hline 18 & Aqueous extract & The developmental toxicity study in pregnant rats & [87] \\
\hline 19 & Sub-fraction 2 of chloroform extract & $\begin{array}{l}\text { Determination of blood glucose level in diabetic rats } \\
\text { Measurement of glucose absorption in the everted rat } \\
\text { jejunum, measurement of glucose uptake in isolated rat } \\
\text { hemi-diaphragms }\end{array}$ & [34] \\
\hline 20 & Methanol extract & Antioxidant activity (DPPH assay) & [48] \\
\hline 21 & Aqueous extract & Effects on glucose uptake and glucose consumption & [77] \\
\hline 22 & $50 \%$ Ethanol extract and sinensetin & $\alpha$-Glucosidase and $\alpha$-amylase inhibitory activity & [68] \\
\hline 23 & Aqueous extract & $\begin{array}{l}\text { Antioxidant activity (ABTS and FRAP assays) } \\
\text { Determination of anti-AGEs formation capacity }\end{array}$ & [51] \\
\hline
\end{tabular}


Table 1. Cont.

\begin{tabular}{clll}
\hline No. & \multicolumn{1}{c}{ Tested Substances } & \multicolumn{1}{c}{ Study Design and Protocol } \\
\hline 24 & Aqueous extract & $\begin{array}{l}\text { Salmonella/microsome mutation assay, mouse bone } \\
\text { marrow micronucleus test }\end{array}$ \\
\hline 25 & Chloroform extract and its sub-fraction 2 & Subcutaneous glucose tolerance test in normal rats & [88] \\
\hline 26 & $50 \%$ Ethanol extract & $\begin{array}{l}\text { Acute toxicity study in rats } \\
\text { Subchronic toxicity study in rats }\end{array}$ \\
\hline 27 & Methanol extract & Acute toxicity study in rats & [86] \\
\hline 28 & Aqueous extract & $\begin{array}{l}\text { Oral glucose tolerance test and plasma analysis in normal } \\
\text { and diabetic rats }\end{array}$ \\
\hline 29 & $\begin{array}{l}\text { Aqueous, 50\% methanol, methanol, 70\% acetone and } \\
\text { chloroform extracts }\end{array}$ & $\begin{array}{l}\text { Antioxidant activity (DPPH assay) } \\
\text { [52] }\end{array}$ \\
\hline 30 & Neoorthosiphonone A & $\begin{array}{l}\text { Assay for inhibitory ability against LPS-induced NO } \\
\text { production in macrophage-like J774.1 cells } \\
\text { [57] }\end{array}$ \\
\hline Siphonols A-E & $\begin{array}{l}\text { Assay for inhibitory ability against LPS-induced NO } \\
\text { production in macrophage-like J774.1 cells }\end{array}$ \\
\hline
\end{tabular}

\section{Clinical Applications}

The medical plant $O$. stamineus has been used in the treatment of some kidney diseases and to improve the renal function for many years in clinical in China, including diabetic nephropathy, chronic nephritis, chronic renal failure, etc. [89].

In a clinical study, the effective rate of the prescription of Cordyceps sinensis and O. stamineus on diabetic nephropathy was $76.7 \%$ among 30 patients. The prescription could decrease the levels of fasting and postprandial blood glucose, glycosylated hemoglobin $(\mathrm{HbA} 1 \mathrm{c})$, urinary protein and serum creatinine, and increase endogenous creatinine clearance rate [90]. In another clinical study, the effective rate of the capsule of Cordyceps sinensis and O. stamineus on diabetic nephropathy was $83.3 \%$ among 30 patients. The capsule could decrease the levels of urine protein, serum creatinine, and urea nitrogen. O. stamineus might have a good effect on diabetic nephropathy by improving the function of renal function [91]. The Chongcaoshencha capsules used in the literature were prepared by Heilongjiang University of Chinese Medicine, including $1 \mathrm{~g}$ Cordyceps sinensis, $40 \mathrm{~g}$ raw Astragalus membranaceus, $2 \mathrm{~g}$ leeches, $10 \mathrm{~g}$ rhubarb, $15 \mathrm{~g}$ Alpinia katsumadai, and $20 \mathrm{~g}$ O. stamineus. Each capsule was $0.45 \mathrm{~g}[92,93]$.

\section{The Pharmacodynamic Material Basis}

\subsection{Phenolic Acids}

There are almost 50 phenolic acids and their derivatives isolated from O. stamineus up to now. The structures of antidiabetic phenolic acids are summarized in Figure 2 and the mechanisms of these compounds are summarized in Table 2. Ferulic acid, methyl caffeate, vanillic acid, protocatechuic acid and rosmarinic acid lower blood glucose level in vivo [94-96]. Salvianolic acid C and rosmarinic acid had been proved to have inhibitory activity on $\alpha$-glucosidase $[97,98]$. Vanillic acid and rosmarinic acid are both antioxidants $[94,99]$. Rosmarinic acid also have anti-inflammatory activity, which reduce NO production and the levels of pro-inflammatory cytokines such as TNF- $\alpha$, IL-1 $\beta$, IL-6 [100,101]. Protocatechuic acid and rosmarinic acid regulate the lipid metabolism in diabetic animals. Protocatechuic acid lowers TC, TG, LDL-C levels and increases HDL-C level $[102,103]$. Methyl caffeate increases hepatic glycogen level and reduces gluconeogenesis through lowering glucose-6-phosphatase activity. It also increases glucose uptake by higher GLUT4 expression [96]. Rosmarinic acid also increases the glucose uptake of muscle cells through activation of adenosine $5^{\prime}$-monophosphate-activated protein kinase (AMPK) phosphorylation and glucose transporter-4 (GLUT4) expression. It promotes insulin secretion and improves insulin resistance by inhibiting dipeptidyl peptidase-4 (DPP-4) and PTB1B [104]. 
DPP-4 is an enzyme which can cleave the peptide bond in GLP-1 and result in a very low affinity between GLP-1 and the receptors. Thus, inhibition of DPP-4 can increase GLP-1 level and lower blood glucose level [105]. Methyl caffeate and rosmarinic acid could protect islet $\beta$-cells [96]. Ferulic acid and rosmarinic acid also have anti-glycation effects to decrease the formation of AGEs [95,106].

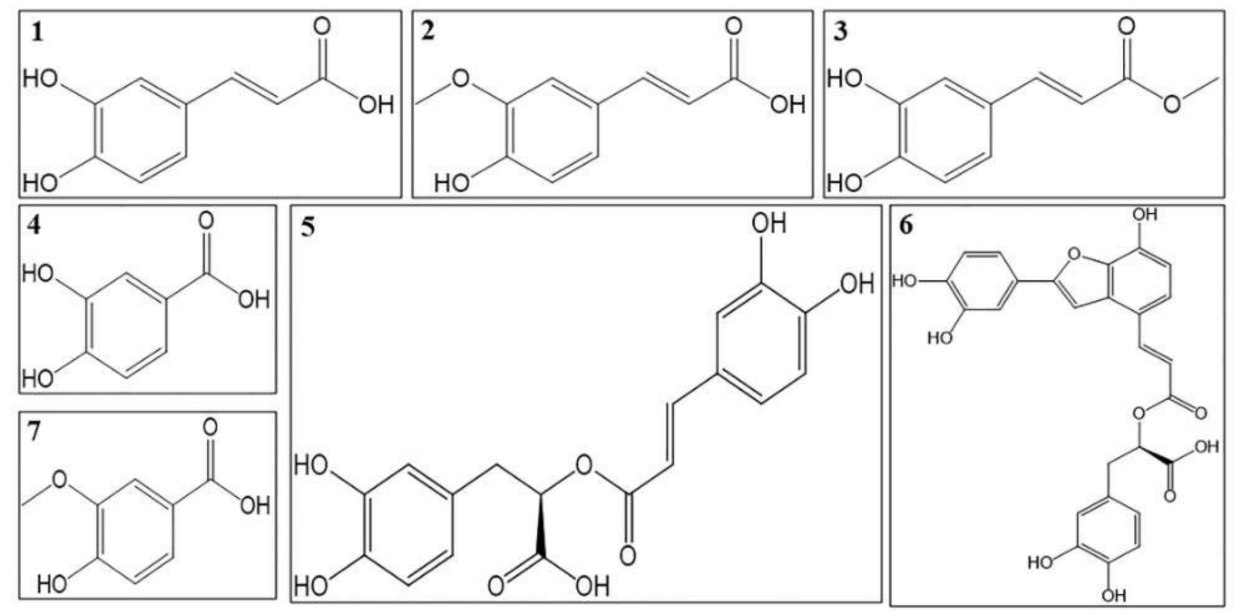

Figure 2. Structures of phenolic acids with antidiabetic effects; (1) Caffeic acid, (2) Ferulic acid, (3) Methyl caffeate, (4) Protocatechuic acid, (5) Rosmarinic acid, (6) Salvianolic acid and (7) Vanillic acid.

For diabetic complications, vanillic acid ameliorated diabetic liver dysfunction by lowering the levels of aspartate aminotransferase (AST) and alanine aminotransferase (ALT). It also decreases the levels of urea, uric acid, and creatinine in kidney [106]. Protocatechuic acid and rosmarinic acid reduce histological changes in kidney tissues in diabetic nephropathy animals $[103,107]$. Ferulic acid and protocatechuic acid increase the activity of SOD in cardiac tissues and decrease cardiomyocytes apoptosis to treat diabetic cardiomyopathy $[95,108]$. For diabetic retinopathy, lithospermic acid B improves oxidative stress in retinal tissues, prevents vascular leakage and basement membrane thickening in retinal capillaries [109].

Table 2. The effects and mechanisms of some phenolic acids in O. stamineus in the treatment of diabetes and diabetic complications.

\begin{tabular}{|c|c|c|c|c|}
\hline No. & Compounds & $\begin{array}{l}\text { Diabetes and Diabetic } \\
\text { Complications }\end{array}$ & Effects and Mechanisms & Ref. \\
\hline 1 & Caffeic acid & Diabetes & Lowers blood glucose level & [110] \\
\hline 2 & Ferulic acid & $\begin{array}{l}\text { Diabetes } \\
\text { Diabetic cardiomyopathy } \\
\text { and liver dysfunction }\end{array}$ & $\begin{array}{l}\text { Lowers blood glucose level; lowers the activities of ALT } \\
\text { and AST in the serum } \\
\text { Decreases the content of AGEs in the liver and heart; } \\
\text { decreases the number of apoptotic hepatocytes and } \\
\text { cardiomyocytes; reduces histological changes in liver } \\
\text { tissues; increases the activity of SOD in the liver and heart }\end{array}$ & [95] \\
\hline 3 & Methyl caffeate & Diabetes & $\begin{array}{l}\text { Lowers blood glucose level; increases hepatic glycogen } \\
\text { level; decreases glucose-6-phosphatase activity; increases } \\
\text { the size and number of islets; increases GLUT4 expression; } \\
\text { improves } \beta \text {-cells }\end{array}$ & [96] \\
\hline 4 & $\begin{array}{l}\text { Protocatechuic } \\
\text { acid }\end{array}$ & $\begin{array}{l}\text { Diabetes } \\
\text { Diabetic nephropathy and } \\
\text { liver dysfunction }\end{array}$ & $\begin{array}{l}\text { Lowers blood glucose level } \\
\text { Decreases lipid hydroperoxides in liver and kidney; } \\
\text { decreases TC, TGs, LDL-C and VLDL-C levels and } \\
\text { increases HDL-C level in liver and kidney; reduces } \\
\text { histological changes in liver and kidney }\end{array}$ & {$[102,103]$} \\
\hline
\end{tabular}


Table 2. Cont.

\begin{tabular}{|c|c|c|c|c|}
\hline No. & Compounds & $\begin{array}{l}\text { Diabetes and Diabetic } \\
\text { Complications }\end{array}$ & Effects and Mechanisms & Ref. \\
\hline \multirow[t]{2}{*}{5} & \multirow[t]{2}{*}{ Rosmarinic acid } & Diabetes & $\begin{array}{l}\text { Reduces blood glucose, TC, TGs and lipid peroxides levels; } \\
\text { inhibitors of } \alpha \text {-amylase, } \alpha \text {-glucosidase, DPP-IV and } \\
\text { PTB1B; lowers the formation of MDA and AGEs; reduces } \\
\text { the levels of pro-inflammatory cytokines such as TNF- } \alpha \text {, } \\
\text { IL-1 } \beta \text {, IL-6, NO and nuclear factor kappa-B (NF- } \mathrm{B} \text { B); } \\
\text { increases the activity of SOD; increases the glucose uptake } \\
\text { of muscle cells through activation of AMPK } \\
\text { phosphorylation; improves insulin sensitivity; increases } \\
\text { GLUT4 expression in skeletal muscle; protects pancreatic } \\
\beta \text {-cells }\end{array}$ & $\begin{array}{l}{[98-101} \\
104,106]\end{array}$ \\
\hline & & $\begin{array}{l}\text { Diabetic vascular } \\
\text { dysfunction }\end{array}$ & $\begin{array}{l}\text { Decreases IL- } 1 \beta \text { and TNF- } \alpha \text { levels and the expression of } \\
\text { endothelin converting enzyme-1; improves structural } \\
\text { alterations in the endothelium }\end{array}$ & [111] \\
\hline 6 & Salvianolic acid C & Diabetic cardiomyopathy & $\begin{array}{l}\text { Enhances intracellular adenosine triphosphate (ATP) } \\
\text { content in the myocardial tissues; reduces ROS, lipid } \\
\text { peroxidation and protein carbonylation level in } \\
\text { myocardial tissues; improves SOD level in cardiac tissues; } \\
\text { reduces histological abnormality }\end{array}$ & [108] \\
\hline 7 & Vanillic acid & $\begin{array}{l}\text { Diabetic nephropathy and } \\
\text { liver dysfunction }\end{array}$ & $\begin{array}{l}\text { Lowers blood glucose level; decreases the concentration of } \\
\text { lipid hydroperoxides } \\
\text { Increases the activities of antioxidants in kidney and liver; } \\
\text { reduces the levels of AST and ALT in liver; decreases the } \\
\text { levels of urea, uric acid, and creatinine in kidney; reduces } \\
\text { histological changes in liver and renal tissues }\end{array}$ & [94] \\
\hline
\end{tabular}

\subsection{Flavonoids}

To date, more than 20 flavonoids have been isolated from O. stamineus. Most of them are flavones, especially polymethoxy substituted flavones. The structures of antidiabetic flavonoids are summarized in Figure 3 and the mechanisms of these compounds are summarized in Table 3. Isoquercitrin, baicalein, and naringenin lower blood glucose level in vivo. They also increase SOD activity, lower MDA level, and regulate lipid metabolism [112-114]. Sinensetin and prunin have inhibitory activity on $\alpha$-glucosidase $[68,115]$. Prunin improves insulin resistance through inhibitory activity against PTP1B and the expression of Akt and PI3K [115]. Isoquercitrin and baicalein increase mRNA expression of IR, Akt, and PI3K to enhance insulin sensitivity $[113,116]$. Prunin and isoquercitrin increase glucose consumption of hepatocytes $[115,116]$. Baicalein promotes glucose uptake and glycolysis by inhibiting the expression of glucose-6-phosphatase, and inhibits gluconeogenesis of hepatocytes [112]. Naringenin increases the expression of GLUT-4 to promote glucose uptake $[117,118]$. Besides, isoquercitrin lowers DPP-IV mRNA levels and increases GLP-1 levels. Isoquercitrin and naringenin protected pancreatic tissues in a histopathological study and improved pancreatic necrosis [116,119].

In diabetic liver dysfunction, isoquercitrin and naringenin reduces serum ALT and AST levels, prevent hepatic apoptosis, and promote the regeneration of hepatocytes [116,120]. Baicalein and naringenin ameliorate diabetic nephropathy by mitigating renal oxidative stress, normalizing serum pro-inflammatory cytokines levels, improving structural changes in renal tissues, and reducing apoptosis [120-123]. Besides, naringenin might also ameliorate diabetic vascular dysfunction, diabetic neuropathy, and diabetic retinopathy [124-126]. 

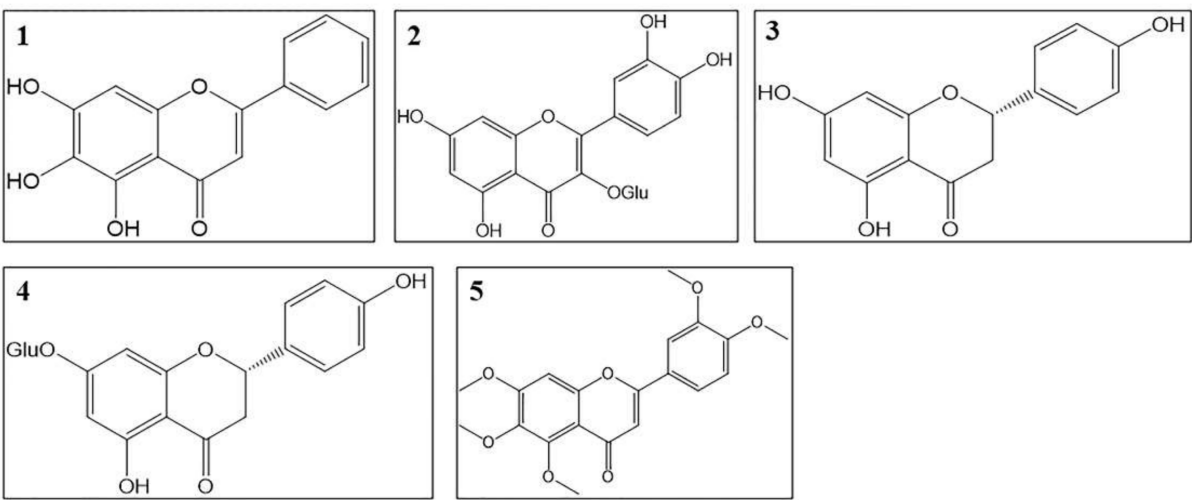

Figure 3. Structures of flavonoids with antidiabetic effects; (1) Baicalein, (2) Isoquercitrin, (3) Naringenin, (4) Prunin and (5) Sinensetin.

Table 3. The effects and mechanisms of some flavonoids in O. stamineus in the treatment of diabetes and diabetic complications.

\begin{tabular}{|c|c|c|c|c|}
\hline No. & Compounds & $\begin{array}{l}\text { Diabetes and Diabetic } \\
\text { Complications }\end{array}$ & Effects and Mechanisms & Ref. \\
\hline \multirow{2}{*}{1} & \multirow{2}{*}{ Baicalein } & Diabetes & $\begin{array}{l}\text { Lowers blood glucose and MDA level; inhibits } \\
\text { gluconeogenesis of hepatocytes; decreases the expressions } \\
\text { of glucose-6-phosphatase; increase SOD activity; promotes } \\
\text { glucose uptake and glycolysis; increases the expression of } \\
\text { PI3K and Akt; increase hepatic glycogen level }\end{array}$ & $\begin{array}{l}{[112,113,} \\
127,128]\end{array}$ \\
\hline & & Diabetic nephropathy & $\begin{array}{l}\text { Lowers HOMA-IR level; restores normal renal function; } \\
\text { mitigates renal oxidative stress; lowers the level of NF-kB; } \\
\text { ameliorates the structural changes in renal tissues; } \\
\text { normalizes the levels of serum pro-inflammatory } \\
\text { cytokines and liver function enzymes }\end{array}$ & [122] \\
\hline
\end{tabular}

\section{Lowers blood glucose, serum HOMA-IR, DPP-IV mRNA}

Diabetes levels; increases glucose uptake of hepatocytes; increases mRNA expression of Akt and PI3K; increases SOD,

2 Isoquercitrin HDL-C, insulin and GLP-1 levels; improves pancreatic atrophy and necrosis

Diabetic liver dysfunction Reduces serum ALT and AST levels; prevents hepatocytes architecture and hepatic necrosis; suppresses apoptosis and promotes regeneration of hepatocytes

Lowers blood glucose, MDA and glycosylated hemoglobin levels; lowers the activities of ALT and AST in serum;

Diabetes increases serum insulin levels; increases the expression of GLUT-4; protects the pancreatic tissues in histopathological study; normalizes lipid concentrations in the serum

Decreases lipid peroxidation level in liver; decreases the

Diabetic liver dysfunction number of vacuolated liver cells and degree of vacuolisation

$3 \quad$ Naringenin

Decreases the 24 h-urinary protein, kidney index and glomerular area; increases creatinine clearance rate; decreases lipid peroxidation level in kidney tissue;

Diabetic nephropathy increases the activity of SOD; decreases renal IL- $1 \beta$, IL-6 and TNF- $\alpha$ levels; lowers NF-kB p65 expression in kidney; improves kidney histology; reduces apoptosis Increases levels of neuroprotective factors, tropomyosin

Diabetic retinopathy related kinase B and synaptophysin in diabetic retina; ameliorates the levels of apoptosis regulatory proteins in 
Table 3. Cont.

\begin{tabular}{lllll}
\hline No. & Compounds & $\begin{array}{c}\text { Diabetes and Diabetic } \\
\text { Complications }\end{array}$ & \multicolumn{1}{c}{ Effects and Mechanisms } & Ref. \\
\hline 4 & Prunin & Diabetes & $\begin{array}{l}\text { Inhibitory activity against PTP1B and } \alpha \text {-glucosidase; } \\
\text { stimulates glucose uptake; increases the expression of } \\
\text { p-Akt and p-PI3K }\end{array}$ & [115] \\
\hline 5 & Sinensetin & Diabetes & Inhibitory activity on $\alpha$-glucosidase and $\alpha$-amylase & [68] \\
\hline
\end{tabular}

\subsection{Triterpenoids}

There are almost 20 triterpenoids isolated from O. stamineus. The structures of antidiabetic triterpenoids are summarized in Figure 4 and the mechanisms of these compounds are summarized in Table 4. $\alpha, \beta$-Amyrin, arjunolic acid, betulinic acid, tormentic acid, oleanolic acid, and ursolic acid lower blood glucose level in vivo. Among them, oleanolic acid and ursolic acid have an inhibitory activity on $\alpha$-glucosidase [130,131]. Arjunolic acid, oleanolic acid, and ursolic acid have antioxidant activities to scavenge free radicals, while oleanolic acid and ursolic acid also have anti-inflammatory activities [100,132-134]. $\alpha, \beta$-Amyrin, arjunolic acid, tormentic acid, oleanolic acid, and ursolic acid lower the levels of TC, TG, LDL-C and leptin, increase serum HDL-C level to regulate the lipid metabolism [133,135-138]. Maslinic acid, oleanolic acid, and ursolic acid improve insulin resistance and enhance insulin sensitivity respectively by a higher expression of IR, IRS, Akt, and PIP1B inhibitory activity $[132,133,139]$. Tormentic acid promotes glucose uptake by increasing the levels of phospho-AMPK and GLUT4 in skeletal muscle [136]. Oleanolic acid inhibits gluconeogenesis by decreasing expression of glucose-6-phosphatase [133]. Maslinic acid and ursolic acid increase the hepatic glycogen accumulation [135,139]. $\alpha, \beta$-Amyrin, arjunolic acid, and betulinic acid protect islet cells and decrease cell death $[138,140,141]$. Oleanolic acid has anti-glycation effects to inhibit the formation of AGEs products [142].
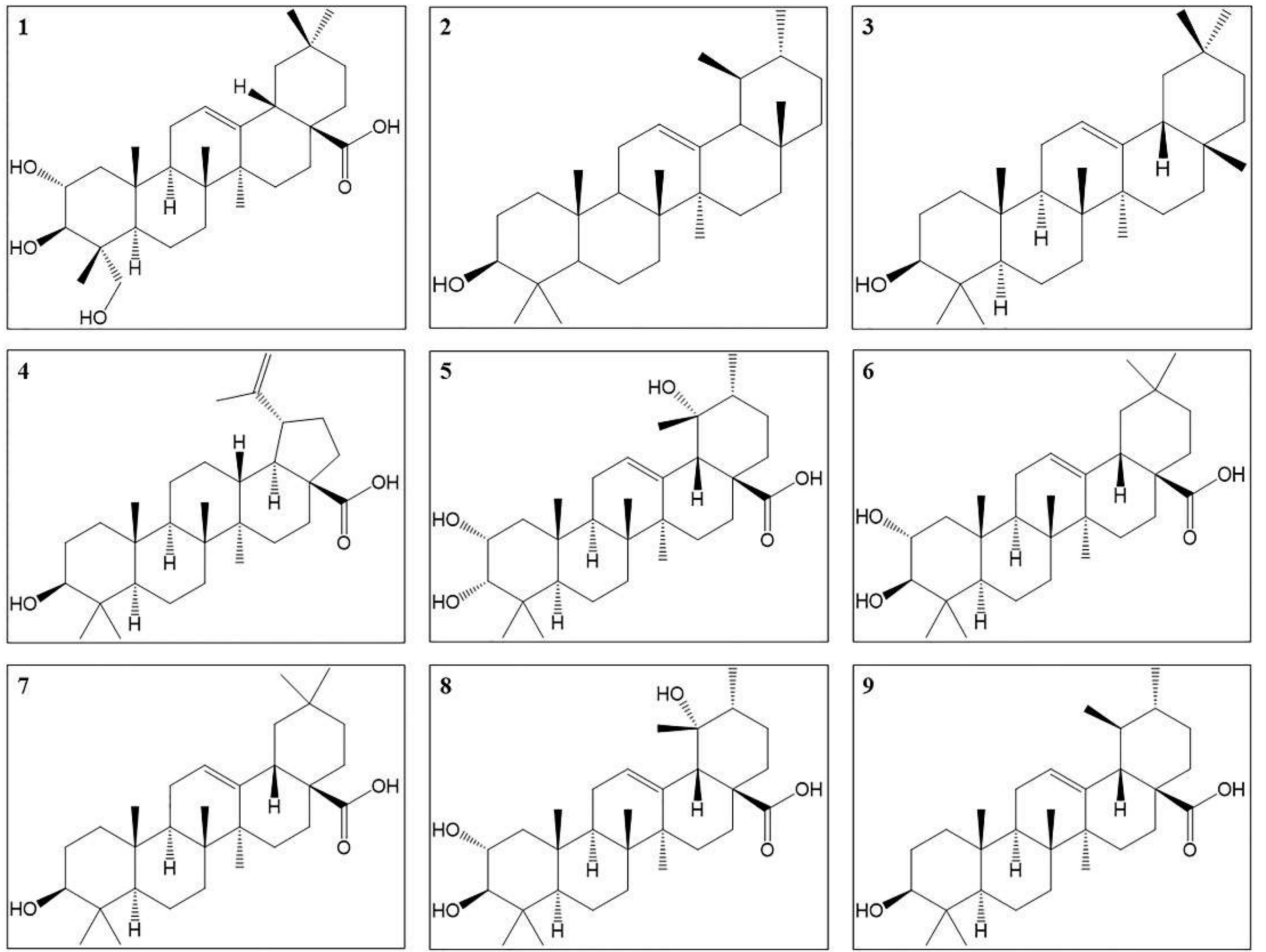

Figure 4. Structures of triterpenoids with antidiabetic effects; (1) Arjunolic acid, (2) $\alpha$-Amyrin, (3) $\beta$ Amyrin, (4) Betulinic acid, (5) Euscaphic acid, (6) Maslinic acid, (7) Oleanolic acid, (8) Tormentic acid and (9) Ursolic acid. 
In diabetic liver dysfunction, arjunolic acid reduces the secretion of ALT and the overproduction of ROS and RNS [141]. While oleanolic acid decreases ROS production, NF- $K B$ expression and IL- $1 \beta$, IL- 6 and TNF- $\alpha$ levels in liver, and increases the activity of SOD [133]. Arjunolic acid and tormentic acid both reduce histological changes in liver tissues $[136,141]$. With regard to diabetic nephropathy, arjunolic acid, ursolic acid, and betulinic acid improve the lesions of renal tissues [143]. Maslinic acid, ursolic acid, and oleanolic acid decrease ROS and MDA levels and increase SOD activity in renal tissues $[133,144,145]$. Arjunolic acid, ursolic acid, and betulinic acid reduce the ratio of kidney weight to body weight, the levels of blood urea nitrogen (BUN), and creatinine. Ursolic acid also lowers urine albumin excretion [141,146,147]. Maslinic acid also increases $\mathrm{Na}^{+}$excretion rate and glomerular filtration rate, and decreases creatinine level $[145,148]$. For diabetic cardiomyopathy, ursolic acid decreases the levels of AGEs, TNF- $\alpha$, IL- $1 \beta$, and ROS, increases the activity of SOD in myocardium [149]. Arjunolic acid reduces histological changes in cardiac tissues and reduces the number of apoptotic cells [137].

Table 4. The effects and mechanisms of some triterpenoids in O. stamineus in the treatment of diabetes and diabetic complications.

\begin{tabular}{|c|c|c|c|c|}
\hline No. & Compounds & $\begin{array}{l}\text { Diabetes and Diabetic } \\
\quad \text { Complications }\end{array}$ & Effects and Mechanisms & Ref. \\
\hline 1 & Arjunolic acid & $\begin{array}{l}\text { Diabetic cardiomyopathy } \\
\text { Diabetic liver dysfunction }\end{array}$ & $\begin{array}{l}\text { Lowers blood glucose, NO, MDA and protein } \\
\text { carbonylation levels; increases the activities of antioxidant } \\
\text { enzymes; increases cell viability and decreases cell death; } \\
\text { reduces pathological lesion; prevents the expression of } \\
\text { c-Jun N-terminal kinase (JNK) } \\
\text { Reduces the levels of vascular inflammation markers; } \\
\text { increases the activities of the antioxidant enzymes and } \\
\text { cellular redox ratio; decreases DNA oxidation in cardiac } \\
\text { tissue; reduces histological changes in cardiac tissues; } \\
\text { reduces the number of apoptotic cells } \\
\text { Reduces the secretion of ALT, the overproduction of ROS } \\
\text { and RNS; reduces histological changes in liver tissues; } \\
\text { prevents cell death } \\
\text { Reduces kidney weight to body weight ratio, glomerular } \\
\text { area, glomerular volume, BUN and creatinine; reduces the } \\
\text { activation of NF- } \mathrm{kB} \text {; prevents cell death; keeps the kidney } \\
\text { close to normal physiological state }\end{array}$ & $\begin{array}{c}{[134,137,} \\
141]\end{array}$ \\
\hline $2-3$ & $\alpha, \beta$-Amyrin & Diabetes & $\begin{array}{l}\text { Lowers blood glucose, LDL, VLDL levels; increases insulin } \\
\text { levels; protects islets of Langerhans }\end{array}$ & [138] \\
\hline 4 & Betulinic acid & Diabetes & $\begin{array}{l}\text { Lowers blood glucose level; improves insulin sensitivity; } \\
\text { decreases insulin resistance by the alternation of some } \\
\text { insulin biomakers; improves pancreatic islets diameter and } \\
\text { number; improves pancreatic histology }\end{array}$ & [140] \\
\hline 5 & Euscaphic acid & Diabetes & $\begin{array}{l}\text { Inhibitory activity on } \alpha \text {-glucosidase and the formation of } \\
\text { Amadori, which is an early product of nonenzymatic } \\
\text { glycosylation }\end{array}$ & [150] \\
\hline 6 & Maslinic acid & Diabetic nephropathy & $\begin{array}{l}\text { Increases hepatic glycogen accumulation; inhibits } \\
\text { glycogen phosphorylase activity; induces the } \\
\text { phosphorylation level of IR } \beta \text { and Akt } \\
\text { Increases the activity of antioxidant enzymes in renal } \\
\text { tissues; increases } \mathrm{Na}^{+} \text {output, } \mathrm{Na}^{+} \text {excretion rates, } \\
\text { fractional excretion of } \mathrm{Na}^{+} ; \text {increases glomerular filtration } \\
\text { rate; decreases plasma aldosterone and creatinine levels; } \\
\text { diminishes the expression of GLUT1 and GLUT2 in } \\
\text { diabetic kidney }\end{array}$ & {$[145,148]$} \\
\hline
\end{tabular}


Table 4. Cont.

\begin{tabular}{|c|c|c|c|c|}
\hline No. & Compounds & $\begin{array}{l}\text { Diabetes and Diabetic } \\
\text { Complications }\end{array}$ & Effects and Mechanisms & Ref. \\
\hline \multirow[t]{2}{*}{7} & \multirow[t]{2}{*}{ Oleanolic acid } & Diabetes & $\begin{array}{l}\text { Lowers blood glucose, LDL and free fatty acids levels; } \\
\text { increases insulin level; inhibitory activity on } \\
\alpha \text {-glucosidase, } \alpha \text {-amylase and PIP1B; inhibits the } \\
\text { formation of AGEs products; improve insulin tolerance; } \\
\text { inhibits gluconeogenesis; increases serum HDL level; } \\
\text { decreases levels of IL-1b, IL- } 6 \text { and TNF } \alpha \text {; increases the } \\
\text { activity of SOD; improve glycogen level by the increasing } \\
\text { expression of Akt and decreasing expression of } \\
\text { glucose-6-phosphatase; increases the expression of IR } \\
\text { and IRS-1 }\end{array}$ & $\begin{array}{l}{[131,133,} \\
142,151]\end{array}$ \\
\hline & & Diabetic liver dysfunction & $\begin{array}{l}\text { Decreases the levels of IL- } 1 \beta, \text { IL- } 6 \text { and TNF } \alpha \text { in liver; } \\
\text { decreases the expression of NF- } \mathrm{kB} \text {; decreases ROS } \\
\text { production; increases the activity of SOD }\end{array}$ & {$[133,152]$} \\
\hline 8 & Tormentic acid & Diabetic liver dysfunction & $\begin{array}{l}\text { Lowers blood glucose, leptin and total lipids levels; } \\
\text { increases the protein contents of phospho-AMPK and } \\
\text { GLUT4 in skeletal muscle } \\
\text { Reduces histological changes in liver tissues; decreases the } \\
\text { mRNA level of glucose- } 6 \text {-phosphatase in liver tissues; } \\
\text { increases the protein contents of hepatic phospho-AMPK }\end{array}$ & [136] \\
\hline \multirow{3}{*}{9} & \multirow{3}{*}{ Ursolic acid } & Diabetes & $\begin{array}{l}\text { Lowers blood glucose, MDA and LDL levels; inhibits } \\
\alpha \text {-amylase and } \alpha \text {-glucosidase activity; increases SOD } \\
\text { activities; decreases TNF- } \alpha \text { and IL- } 1 \beta \text { level; increases liver } \\
\text { glycogen level; decreases the expression of PTP-1B protein; } \\
\text { increases the expression of IRS-2 protein }\end{array}$ & $\begin{array}{c}{[130,132,} \\
135]\end{array}$ \\
\hline & & Diabetic cardiomyopathy & $\begin{array}{l}\text { Decreases levels of AGEs, TNF- } \alpha \text {, IL- } 1 \beta \text { and ROS; } \\
\text { increases the activity of SOD in myocardium }\end{array}$ & [149] \\
\hline & & Diabetic nephropathy & $\begin{array}{l}\text { Lowers the levels of BUN, creatinine and MDA; lowers } \\
\text { urine albumin excretion, renal oxidative stress level, } \\
\text { NF-kB activity; prevents the expression of JNK; improves } \\
\text { renal structural abnormalities }\end{array}$ & $\begin{array}{c}{[144,146,} \\
147]\end{array}$ \\
\hline
\end{tabular}

\section{Discussion}

O. stamineus is a potential natural product to treat diabetes and its complications. The mechanisms of $O$. stamineus in the treatment of diabetes and its complications are summarized in Figure 5. The antioxidant activity, anti-inflammatory activity, anti-glycation activity and lipid metabolism regulation are all related to antidiabetic activity. O. stamineus protects the islet cells, enhances insulin sensitivity, and improves diabetic complications by lowering the levels of free radicals and inflammatory factors. It also improves insulin resistance by lowering the levels of free fatty acids and leptin. The lower level of AGEs is able to improve diabetic complications. Besides, $O$. stamineus enhances insulin sensitivity and improves insulin resistance through other pathways, such as the PI3k/Akt signaling pathway, the AMPK pathway, and the JNK pathway (summarized in Figure 6) [153-155]. The PTP1B activity might also be related to the PI3k/Akt pathway. Some diterpenes isolated from O. stamineus had inhibitory activity on PTP1B. The hexane fraction of $70 \%$ ethanol extract and some flavonoids (prunin, isoquercitrin, baicalein) can increase the expression of PI3K and Akt. Rosmarinic acid and tormentic acid could increase the expression phospho-AMPK. Arjunolic acid and ursolic acid prevent the expression of JNK. In addition, O. stamineus reduces glucose absorption from the small intestine by inhibiting the activities of $\alpha$-amylase and $\alpha$-glucosidase, promotes insulin secretion by elevating PDX-1 level, and lowers GLP-1 level. It could also promote glycolysis and inhibit gluconeogenesis by inhibiting glucose-6phosphatase. However, some current experiments have only studied the antidiabetic effects and results of $O$. stamineus, such as reducing blood glucose level, improving insulin level, increasing glucose uptake, and reducing glucose absorption, without further exploration of 
its mechanisms and pathways. The relationship between O. stamineus extracts and AMPK, JNK pathways should be further studied.

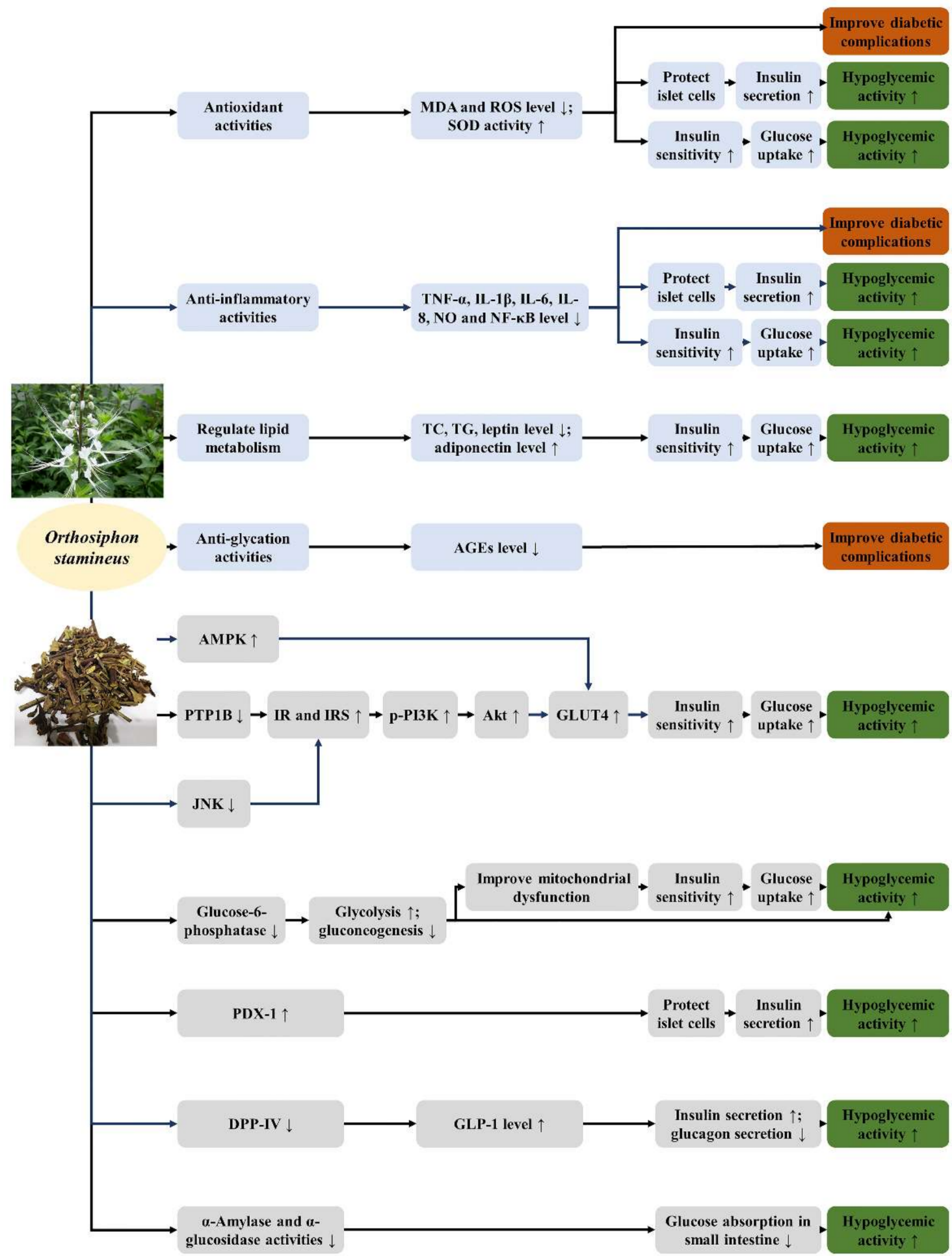

Figure 5. The mechanisms of $O$. stamineus in the treatment of diabetes and its complications. (The blue part shows other activities related to antidiabetic activity. The grey part is the pathways, targets, and enzymes related to antidiabetic activity). 


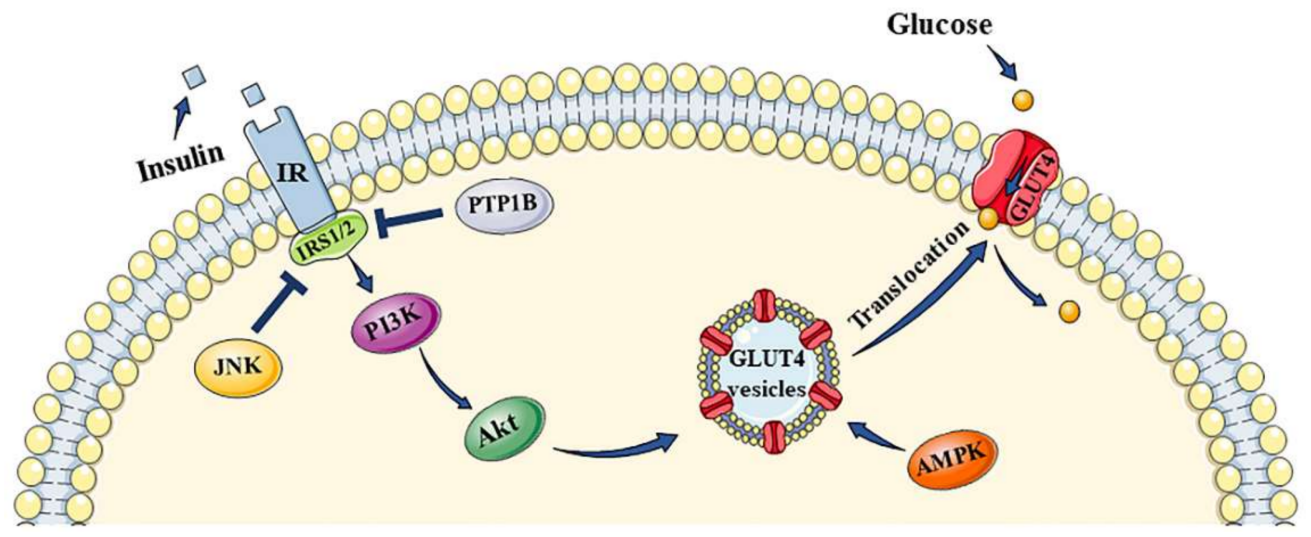

Figure 6. Summary of the PI3K/Akt, AMPK, JNK signal pathways related to insulin resistance. Arrows indicate activation, thick lines indicate inhibition.

Until now, investigations on the antidiabetic effects and mechanisms of $O$. stamineus have concentrated mainly on the effects of extracts, especially $50 \%$ ethanol extract and aqueous extract. The effects of extracts might be different because the levels of some metabolites vary in the plant from different places. Through literature research, it was seen that phenolic acids, flavonoids, and triterpenoids might be the main active components to treat diabetes and complications. To identify the major bioactive compounds responsible for antidiabetic effects, bioassay-guided isolation should be used. The mechanisms of pure compounds are also required to study, and there might be synergistic effects between these constituents.

In China and some southeastern Asian countries, O. stamineus has been used as traditional medicine for the treatment of diabetes and some kidney diseases for a long time. In recent years, by means of modern science and techniques, there have been more and more investigations in the mechanisms of $O$. stamineus in the treatment of diabetes and diabetic complications. However, most experiments are in vitro or using experimental animal models in vivo, which may be different from the effects and mechanisms of O. stamineus in the human body. In addition, clinical research is very limited. O. stamineus was only used to treat chronic renal diseases in clinical, such as chronic glomerulonephritis [156]. But because O. stamineus might be a good antidiabetic candidate to reduce blood glucose levels and alleviate kidney injury, it could also be designed to study the clinical treatment of diabetic nephropathy in the future.

At present, diabetes is treated with oral hypoglycemic drugs and insulin injections. The glucose-lowering drugs include $\alpha$-glucosidase inhibitors (acarbose, miglitol), insulin sensitizers (metformin, thiazolidinediones, biguanides), insulin secretagogues (sulfonylureas), etc. However, most of these medications may have side-effects, including hypoglycemia, weight gain, liver damage, gastrointestinal disturbance, lactic acidosis, edema, headache, dizziness, anemia, nausea, and even death. Besides, long-term use of insulin may decrease insulin receptor sensitivity, resulting in insulin resistance [157]. In the future, glucoselowering drugs might be combined with $O$. stamineus to find out if they can reduce these side-effects and increase antidiabetic effects. Besides, some other natural products with antidiabetic activities can also be used with $O$. stamineus to test the combined effects in the treatment of diabetes and diabetic complications. Cordyceps sinensis, Astragalus membranaceus, Rheum officinale, and leech have been combined with O. stamineus to treat diabetic nephropathy as a Chinese traditional medicine prescription [91].

\section{Methods}

This review was performed and reported according to PRISMA guidelines [37,38]. The flowchart of selected articles is shown in Figure 1. 


\subsection{Search Strategy}

Three databases (ScienceDirect, PubMed and Web of Science) were used to search relevant articles using the terms "((Clerodendranthus spicatus) OR (Orthosiphon stamineus) OR (Orthosiphon aristatus)) AND ((diabetes) OR (antidiabetic) OR (hypoglycemic) OR (diabetic complications))". No time restriction was used. The initial search included 281 articles. The results of ScienceDirect, PubMed, and Web of Science were respectively exported as RIS, NBIB, and ISI files. All obtained files were then imported into EndNote X9 to generate a library.

\subsection{Eligibility Criteria}

The research included in this review met the following criteria: 1. the study reported hypoglycemic activity or the treatment of diabetes and its complications of O. stamineus extract or its isolated compounds, 2. the study reported other biological activities related to diabetes treatment, such as antioxidant and anti-inflammatory activities, of $O$. stamineus extract or its isolated compounds, 3. the study reported the toxicity of $O$. stamineus extract or its isolated compounds.

The exclusion criteria of this review were as follows: 1 . reviews, book chapters, patents, meeting papers, 2. non-English language papers, 3. lack of access to the full-text of the paper, 4 . no relevance to the plant $O$. stamineus or the field of diabetes and its complications. Besides, duplicate articles were also removed.

\subsection{Data Extraction}

Thirty-one studies met the criteria, and the data were extracted into Microsoft Excel 2007 sheet and inserted to Table 1. The information gathered from the studies included: 1. name of the first author, 2. publication year, 3 . the tested substance, 4 . the study design and protocol, 5. main results.

\section{Conclusions}

In conclusion, O. stamineus is a potential agent to treat diabetes and diabetic complications. The extracts of $O$. stamineus, including $50 \%$ ethanol extract, chloroform extract, aqueous extract, and hexane extract, could be used to treat diabetes through mechanisms including inhibiting the activities of $\alpha$-amylase and $\alpha$-glucosidase, antioxidant and anti-inflammatory activities, regulating lipid metabolism, promoting insulin secretion, ameliorating insulin resistance, enhancing insulin sensitivity, increasing glucose uptake, promoting glycolysis, inhibiting gluconeogenesis, promoting the secretion of GLP-1, and antiglycation effects. The mechanisms of insulin resistance might also be related to the PI3k/Akt signaling pathway, the AMPK pathway, and the JNK pathway. The aqueous extract could also be used for diabetic nephropathy treatment. Besides, some main active components, such as rosmarinic acid, ferulic acid, methyl caffeate, vanillic acid, protocatechuic acid, isoquercitrin, baicalein, naringenin, arjunolic acid, betulinic acid, tormentic acid, oleanolic acid, ursolic acid, maslinic acid, siphonols B, orthosiphols B, G, I, and N also had good effects in the treatment of diabetes and its complications. However, it needs further study on pharmacodynamic substance basis and the mechanisms of effective constituents.

Author Contributions: Conceptualization, H.C.; methodology, Q.W.; software, J.L.; validation, N.L.; formal analysis, J.Z.; investigation, Q.W.; resources, H.C.; data curation, Q.W.; writing—original draft preparation, Q.W.; writing —review and editing, J.W.; visualization, J.L.; supervision, P.Z.; project administration, Q.W.; funding acquisition, H.C. All authors have read and agreed to the published version of the manuscript.

Funding: This research was funded by a grant from National Key Research and Development Program of China, grant number 2021YFE0110000.

Institutional Review Board Statement: Not applicable.

Informed Consent Statement: Not applicable. 
Data Availability Statement: Not applicable.

Conflicts of Interest: The authors declare no conflict of interest.

\section{References}

1. Shafaei, A.; Halim, N.H.A.; Zakaria, N.; Ismail, Z. Analysis of Free Amino Acids in Different Extracts of Orthosiphon stamineus Leaves by High-Performance Liquid Chromatography Combined with Solid-Phase Extraction. Pharmacogn. Mag. 2017, 13 (Suppl. S3), 385-391.

2. Guan, S.C.; Fan, G.Y. Diterpenoids from Aerial Parts of Clerodendranthus spicatus and Their Cytotoxic Activity. Helv. Chim. Acta 2014, 97, 1708-1713. [CrossRef]

3. Zhou, H.C.; Yang, L.; Guo, R.Z.; Li, J. Phenolic acid derivatives with neuroprotective effect from the aqueous extract of Clerodendranthus spicatus. J. Asian Nat. Prod. Res. 2017, 19, 974-980. [CrossRef]

4. Gan, S.H.; Tham, T.C.; Ng, M.X.; Chua, L.S.; Aziz, R.; Baba, M.R.; Abdullah, L.C.; Ong, S.P.; Law, C.L. Study on retention of metabolites composition in misai kucing (Orthosiphon stamineus) by heat pump assisted solar drying. J. Food Processing Preserv. 2017, 41, e13262. [CrossRef]

5. Luo, Y.; Cheng, L.Z.; Luo, Q.; Yan, Y.M.; Wang, S.M.; Sun, Q.; Cheng, Y.X. New ursane-type triterpenoids from Clerodendranthus spicatus. Fitoterapia 2017, 119, 69-74. [CrossRef]

6. Sun, Z.; Zheng, Q.; Ma, G.; Zhang, X.; Yuan, J.; Wu, H.; Liu, H.; Yang, J.; Xu, X. Four new phenolic acids from Clerodendranthus spicatus. Phytochem. Lett. 2014, 8, 16-21. [CrossRef]

7. Robaina-Mesa, M.; López-Hernández, O.D.; Rodríguez-Chanfrau, J.E.; Nogueira-Mendoza, A. Spray dried aqueous extract of Orthosiphon aristatus Blume (Java tea). Braz. J. Pharm. Sci. 2017, 53, 1-5. [CrossRef]

8. Chung, Y.S.; Choo, B.K.M.; Ahmed, P.K.; Othman, I.; Shaikh, M.F. A Systematic Review of the Protective Actions of Cat's Whiskers (Misai Kucing) on the Central Nervous System. Front. Pharm. 2020, 11, 692. [CrossRef]

9. Yuliana, N.D.; Khatib, A.; Link-Struensee, A.M.R.; Ijzerman, A.P.; Rungkat-Zakaria, F.; Choi, Y.H.; Verpoorte, R. Adenosine A(1) Receptor Binding Activity of Methoxy Flavonoids from Orthosiphon stamineus. Planta Med. 2009, 75, 132-136. [CrossRef]

10. Yoshimura, H.; Sugawara, K.; Saito, M.; Saito, S.; Murakami, S.; Miyata, N.; Kawashima, A.; Morimoto, S.; Gao, N.; Zhang, X.G.; et al. In vitro TGF-beta 1 antagonistic activity of ursolic and oleanolic acids isolated from Clerodendranthus spicatus. Planta Med. 2003, 69, 673-675.

11. Hashim, S.; Beh, H.K.; Hamil, M.S.R.; Ismail, Z.; Majid, A. High-performance thin-layer chromatography method development, validation, and simultaneous quantification of four compounds identified in standardized extracts of Orthosiphon stamineus. Pharmacogn. Res. 2016, 8, 238-243.

12. Saidan, N.H.; Aisha, A.F.; Hamil, M.S.; Majid, A.M.; Ismail, Z. A novel reverse phase high-performance liquid chromatography method for standardization of Orthosiphon stamineus leaf extracts. Pharmacogn. Res. 2015, 7, 23-31.

13. Heryanto, R.; Pradono, D.I.; Marlina, E.; Darusman, L.K. Classification of java tea (Orthosiphon aristatus) quality using FTIR spectroscopy and chemometrics. In International Symposium on Bioinformatics, Chemometrics and Metabolomics; Kusuma, W.A., Rohman, A., Putri, S.P., Eds.; Iop Publishing Ltd.: Bristol, UK, 2017; Volume 835.

14. Febriani, Y.; Fidrianny, I.; Elfahmi. Isolation of two methoxy flavonoid compounds from kumis kucing (Orthoshipon stamineus, Benth.) a popular plant in Indonesian herbal medicine Jamu. Res. J. Pharm. Biol. Chem. Sci. 2017, 8, 1640-1646.

15. Li, Y.M.; Xiang, B.; Li, X.Z.; Yan, Y.M.; Cheng, Y.X. New Diterpenoids from Clerodendranthus spicatus. Nat. Prod. Bioprospect. 2017, 7, 263-267. [CrossRef]

16. Ma, G.X.; Zhang, X.P.; Li, P.F.; Sun, Z.H.; Zhu, N.L.; Zhu, Y.D.; Yang, J.S.; Chen, D.L.; Wu, H.F.; Xu, X.D. Four new phenolic acid with unusual bicycle [2.2.2] octane moiety from Clerodendranthus spicatus and their anti-inflammatory activity. Fitoterapia 2015, 105, 61-65. [CrossRef]

17. American Diabetes Association, Diagnosis and classification of diabetes mellitus. Diabetes Care 2014, 37 (Suppl. S1), 81-90. [CrossRef]

18. Federation, I.D. IDF Diabetes Atlas, 10th ed.; International Diabetes Federation: Brussels, Belgium, 2021.

19. Prabhakar, P.K.; Doble, M. Mechanism of action of natural products used in the treatment of diabetes mellitus. Chin. J. Integr Med. 2011, 17, 563-574. [CrossRef]

20. Choudhury, H.; Pandey, M.; Hua, C.K.; Mun, C.S.; Jing, J.K.; Kong, L.; Ern, L.Y.; Ashraf, N.A.; Kit, S.W.; Yee, T.S.; et al. An update on natural compounds in the remedy of diabetes mellitus: A systematic review. J. Tradit. Complement. Med. 2018, 8, 361-376. [CrossRef]

21. Xu, L.; Li, Y.; Dai, Y.; Peng, J. Natural products for the treatment of type 2 diabetes mellitus: Pharmacology and mechanisms. Pharm. Res. 2018, 130, 451-465. [CrossRef]

22. Wehmeier, U.F.; Piepersberg, W. Biotechnology and molecular biology of the alpha-glucosidase inhibitor acarbose. Appl. Microbiol. Biotechnol. 2004, 63, 613-625. [CrossRef]

23. Furman, B.L. The development of Byetta (exenatide) from the venom of the Gila monster as an anti-diabetic agent. Toxicon 2012, 59, 464-471. [CrossRef]

24. Fu, Y. Historical story on natural medicinal chemistry: 60 years history of metformin, a classical antidiabetic drug originated from Galega officinalis. Chin. Tradit. Herbal Drugs 2017, 48, 4591-4600. 
25. Wang, S.; Lu, A.; Zhang, L.; Shen, M.; Xu, T.; Zhan, W.; Jin, H.; Zhang, Y.; Wang, W. Extraction and purification of pumpkin polysaccharides and their hypoglycemic effect. Int. J. Biol. Macromol. 2017, 98, 182-187. [CrossRef]

26. Zhao, R.; Jin, R.; Chen, Y.; Han, F.-M. Hypoglycemic and Hypolipidemic Effects of Lycium barbarum Polysaccharide in Diabetic Rats. Chin. Herb. Med. 2015, 7, 310-315. [CrossRef]

27. Bai, Y.; Zang, X.; Ma, J.; Xu, G. Anti-Diabetic Effect of Portulaca oleracea L. Polysaccharideandits Mechanism in Diabetic Rats. Int. J. Mol. Sci. 2016, 17, 1201. [CrossRef] [PubMed]

28. Zheng, Q.; Sun, Z.; Zhang, X.; Yuan, J.; Wu, H.; Yang, J.; Xu, X. Clerodendranoic acid, a new phenolic acid from Clerodendranthus spicatus. Molecules 2012, 17, 13656-13661. [CrossRef] [PubMed]

29. Hossain, M.A.; Mizanur Rahman, S.M. Isolation and characterisation of flavonoids from the leaves of medicinal plant Orthosiphon stamineus. Arab. J. Chem. 2015, 8, 218-221. [CrossRef]

30. Nguyen, M.T.T.; Awale, S.; Tezuka, Y.; Chien-Hsiung, C.; Kadota, S. Staminane- and isopimarane-type diterpenes from Orthosiphon stamineus of Taiwan and their nitric oxide inhibitory activity. J. Nat. Prod. 2004, 67, 654-658. [CrossRef] [PubMed]

31. Awale, S.; Tezuka, Y.; Banskota, A.H.; Adnyana, I.K.; Kadota, S. Highly-oxygenated isopimarane-type diterpenes from Orthosiphon stamineus of Indonesia and their nitric oxide inhibitory activity. Chem. Pharm. Bull. 2003, 51, 268-275. [CrossRef]

32. Hossain, M.A.; Ismail, Z. Isolation and characterization of triterpenes from the leaves of Orthosiphon stamineus. Arab. J. Chem. 2013, 6, 295-298. [CrossRef]

33. Adam, Y.; Somchit, M.N.; Sulaiman, M.R.; Nasaruddin, A.A.; Zuraini, A.; Bustamam, A.A.; Zakaria, Z.A. Diuretic properties of Orthosiphon stamineus Benth. J. Ethnopharmacol. 2009, 124, 154-158. [CrossRef]

34. Mohamed, E.A.H.; Yam, M.F.; Ang, L.F.; Mohamed, A.J.; Asmawi, M.Z. Antidiabetic Properties and Mechanism of Action of Orthosiphon stamineus Benth Bioactive Sub-fraction in Streptozotocin-induced Diabetic Rats. J. Acupunct. Meridian Stud. 2013, 6, 31-40. [CrossRef] [PubMed]

35. Ameer, O.Z.; Salman, I.M.; Asmawi, M.Z.; Ibraheem, Z.O.; Yam, M.F. Orthosiphon stamineus: Traditional uses, phytochemistry, pharmacology, and toxicology. J. Med. Food 2012, 15, 678-690. [CrossRef] [PubMed]

36. Ashraf, K.; Sultan, S.; Adam, A. Orthosiphon stamineus Benth. is an Outstanding Food Medicine: Review of Phytochemical and Pharmacological Activities. J. Pharm. Bioallied. Sci. 2018, 10, 109-118. [CrossRef]

37. Page, M.J.; Moher, D.; Bossuyt, P.M.; Boutron, I.; Hoffmann, T.C.; Mulrow, C.D.; Shamseer, L.; Tetzlaff, J.M.; Akl, E.A.; Brennan, S.E.; et al. PRISMA 2020 explanation and elaboration: Updated guidance and exemplars for reporting systematic reviews. BMJ 2021, 372, n160. [CrossRef] [PubMed]

38. Page, M.J.; McKenzie, J.E.; Bossuyt, P.M.; Boutron, I.; Hoffmann, T.C.; Mulrow, C.D.; Shamseer, L.; Tetzlaff, J.M.; Akl, E.A.; Brennan, S.E.; et al. The PRISMA 2020 statement: An updated guideline for reporting systematic reviews. BMJ 2021, 372, n71. [CrossRef]

39. Luo, Y.; Liu, Y.; Wen, Q.; Feng, Y.; Tan, T. Comprehensive chemical and metabolic profiling of anti-hyperglycemic active fraction from Clerodendranthi Spicati Herba. J. Sep. Sci. 2021, 44, 1824-1832. [CrossRef]

40. Seyedan, A.; Alshawsh, M.A.; Alshagga, M.A.; Mohamed, Z. Antiobesity and Lipid Lowering Effects of Orthosiphon stamineus in High-Fat Diet-Induced Obese Mice. Planta Med. 2017, 83, 684-692. [CrossRef]

41. Mohamed, E.A.; Ahmad, M.; Ang, L.F.; Asmawi, M.Z.; Yam, M.F. Evaluation of alpha-Glucosidase Inhibitory Effect of 50\% Ethanolic Standardized Extract of Orthosiphon stamineus Benth in Normal and Streptozotocin-Induced Diabetic Rats. Evid.-Based Complement. Altern. Med. 2015, 2015, 754931. [CrossRef]

42. Mohamed, E.A.H.; Mohamed, A.J.; Asmawi, M.Z.; Sadikun, A.; Ebrika, O.S.; Yam, M.F. Antihyperglycemic effect of orthosiphon stamineus benth leaves extract and its bioassay-guided fractions. Molecules 2011, 16, 3787-3801. [CrossRef]

43. Sriplang, K.; Adisakwattana, S.; Rungsipipat, A.; Yibchok-anun, S. Effects of Orthosiphon stamineus aqueous extract on plasma glucose concentration and lipid profile in normal and streptozotocin-induced diabetic rats. J. Ethnopharmacol. 2007, 109, 510-514. [CrossRef] [PubMed]

44. Shori, A.B. Screening of antidiabetic and antioxidant activities of medicinal plants. J. Integr. Med. 2015, 13, 297-305. [CrossRef]

45. Umeno, A.; Horie, M.; Murotomi, K.; Nakajima, Y.; Yoshida, Y. Antioxidative and Antidiabetic Effects of Natural Polyphenols and Isoflavones. Molecules 2016, 21, 708. [CrossRef] [PubMed]

46. Batubara, I.; Komariah, K.; Sandrawati, A.; Nurcholis, W. Genotype selection for phytochemical content and pharmacological activities in ethanol extracts of fifteen types of Orthosiphon aristatus (Blume) Miq. leaves using chemometric analysis. Sci. Rep. 2020, 10, 20945. [CrossRef]

47. Lau, C.H.; Chua, L.S. Solvation Free Energy Simulation for Rosmarinic Acid Extraction from Orthosiphon stamineus. Methods Protoc. 2019, 2, 64. [CrossRef] [PubMed]

48. Lim, F.L.; Yam, M.F.; Asmawi, M.Z.; Chan, L.-K. Elicitation of Orthosiphon stamineus cell suspension culture for enhancement of phenolic compounds biosynthesis and antioxidant activity. Ind. Crops Prod. 2013, 50, 436-442. [CrossRef]

49. Chua, L.S.; Lau, C.H.; Chew, C.Y.; Ismail, N.I.M.; Soontorngun, N. Phytochemical profile of Orthosiphon aristatus extracts after storage: Rosmarinic acid and other caffeic acid derivatives. Phytomedicine 2018, 39, 49-55. [CrossRef] [PubMed]

50. Ismail, H.F.; Hashim, Z.; Soon, W.T.; Rahman, N.S.A.; Zainudin, A.N.; Majid, F.A.A. Comparative study of herbal plants on the phenolic and flavonoid content, antioxidant activities and toxicity on cells and zebrafish embryo. J. Tradit. Complement. Med. 2017, 7, 452-465. [CrossRef] 
51. Deetae, P.; Parichanon, P.; Trakunleewatthana, P.; Chanseetis, C.; Lertsiri, S. Antioxidant and anti-glycation properties of Thai herbal teas in comparison with conventional teas. Food Chem. 2012, 133, 953-959. [CrossRef]

52. Akowuah, G.A.; Ismail, Z.; Norhayati, I.; Sadikun, A. The effects of different extraction solvents of varying polarities on polyphenols of Orthosiphon stamineus and evaluation of the free radical-scavenging activity. Food Chem. 2005, 93, 311-317. [CrossRef]

53. Cai, X.; Xiao, C.; Xue, H.; Xiong, H.; Hang, Y.; Xu, J.; Lu, Y. A comparative study of the antioxidant and intestinal protective effects of extracts from different parts of Java tea (Orthosiphon stamineus). Food Sci. Nutr. 2018, 6, 579-584. [CrossRef] [PubMed]

54. Kothari, V.; Galdo, J.A.; Mathews, S.T. Hypoglycemic agents and potential anti-inflammatory activity. J. Inflamm. Res. 2016, 9 , 27-38. [PubMed]

55. Li, Z.; Geng, Y.N.; Jiang, J.D.; Kong, W.J. Antioxidant and anti-inflammatory activities of berberine in the treatment of diabetes mellitus. Evid Based Complement. Altern. Med. 2014, 2014, 1-12. [CrossRef]

56. Chen, W.-D.; Zhao, Y.-L.; Dai, Z.; Zhou, Z.-S.; Zhu, P.-F.; Liu, Y.-P.; Zhao, L.-X.; Luo, X.-D. Bioassay-guided isolation of antiinflammatory diterpenoids with highly oxygenated substituents from kidney tea (Clerodendranthus spicatus). J. Food Biochem. 2020, 44, e13511. [CrossRef]

57. Awale, S.; Tezuka, Y.; Kobayashi, M.; Ueda, J.-Y.; Kadota, S. Neoorthosiphonone A; a nitric oxide (NO) inhibitory diterpene with new carbon skeleton from Orthosiphon stamineus. Tetrahedron Lett. 2004, 45, 1359-1362. [CrossRef]

58. Awale, S.; Tezuka, Y.; Banskota, A.H.; Kadota, S. Siphonols A-E: Novel nitric oxide inhibitors from Orthosiphon stamineus of Indonesia. Bioorg. Med. Chem. Lett. 2003, 13, 31-35. [CrossRef]

59. Jaiswal, M.; Schinske, A.; Pop-Busui, R. Lipids and lipid management in diabetes. Best Pr. Res. Clin. Endocrinol. Metab. 2014, 28, 325-338. [CrossRef]

60. Mosavat, M.; Mirsanjari, M.; Arabiat, D.; Smyth, A.; Whitehead, L. The Role of Sleep Curtailment on Leptin Levels in Obesity and Diabetes Mellitus. Obes. Facts 2021, 14, 214-221. [CrossRef] [PubMed]

61. Howlader, M.; Sultana, M.I.; Akter, F.; Hossain, M.M. Adiponectin gene polymorphisms associated with diabetes mellitus: A descriptive review. Heliyon 2021, 7, e07851. [CrossRef]

62. Lokman, E.F.; Saparuddin, F.; Muhammad, H.; Omar, M.H.; Zulkapli, A. Orthosiphon stamineus as a potential antidiabetic drug in maternal hyperglycemia in streptozotocin-induced diabetic rats. Integr. Med. Res. 2019, 8, 173-179. [CrossRef]

63. Azam, A.A.; Pariyani, R.; Ismail, I.S.; Ismail, A.; Khatib, A.; Abas, F.; Shaari, K. Urinary metabolomics study on the protective role of Orthosiphon stamineus in Streptozotocin induced diabetes mellitus in rats via H-1 NMR spectroscopy. BMC Complement. Altern. Med. 2017, 17, 278. [CrossRef] [PubMed]

64. Xia, X.; Sun, B.; Li, W.; Zhang, X.; Zhao, Y. Anti-Diabetic Activity Phenolic Constituents from Red Wine Against $\alpha$-Glucosidase and $\alpha$-Amylase. J. Food Processing Preserv. 2017, 41, e12942. [CrossRef]

65. Yang, C.Y.; Yen, Y.Y.; Hung, K.C.; Hsu, S.W.; Lan, S.J.; Lin, H.C. Inhibitory effects of pu-erh tea on alpha glucosidase and alpha amylase: A systemic review. Nutr. Diabetes 2019, 9, 23. [CrossRef] [PubMed]

66. Zhu, C.; Niu, H.; Nie, A.; Bian, M. Bioactivity-guided separation of potential alpha-glycosidase inhibitor from clerodendranthus spicatus based on HSCCC coupled with molecular docking. Sci. Rep. 2021, 11, 6914. [CrossRef]

67. Thengyai, S.; Thiantongin, P.; Sontimuang, C.; Ovatlarnporn, C.; Puttarak, P. $\alpha$-Glucosidase and $\alpha$-amylase inhibitory activities of medicinal plants in Thai antidiabetic recipes and bioactive compounds from Vitex glabrata R. Br. stem bark. J. Herb. Med. 2020, 19, 100302. [CrossRef]

68. Mohamed, E.A.H.; Siddiqui, M.J.A.; Ang, L.F.; Sadikun, A.; Chan, S.H.; Tan, S.C.; Asmawi, M.Z.; Yam, M.F. Potent alphaglucosidase and alpha-amylase inhibitory activities of standardized 50\% ethanolic extracts and sinensetin from Orthosiphon stamineus Benth as anti-diabetic mechanism. BMC Complement. Altern. Med. 2012, 12, 176. [CrossRef]

69. Schofield, C.J.; Sutherland, C. Disordered insulin secretion in the development of insulin resistance and Type 2 diabetes. Diabet. Med. 2012, 29, 972-979. [CrossRef] [PubMed]

70. Huang, X.; Liu, G.; Guo, J.; Su, Z. The PI3K/AKT pathway in obesity and type 2 diabetes. Int. J. Biol. Sci. 2018, 14, 1483-1496. [CrossRef]

71. Schultze, S.M.; Hemmings, B.A.; Niessen, M.; Tschopp, O. PI3K/AKT, MAPK and AMPK signalling: Protein kinases in glucose homeostasis. Expert Rev. Mol. Med. 2012, 14, e1. [CrossRef]

72. Bakke, J.; Haj, F.G. Protein-tyrosine phosphatase 1B substrates and metabolic regulation. Semin. Cell Dev. Biol. 2015, 37, 58-65. [CrossRef]

73. Sharma, B.; Xie, L.; Yang, F.; Wang, W.; Zhou, Q.; Xiang, M.; Zhou, S.; Lv, W.; Jia, Y.; Pokhrel, L.; et al. Recent advance on PTP1B inhibitors and their biomedical applications. Eur. J. Med. Chem. 2020, 199, 112376. [CrossRef] [PubMed]

74. Phi Hung, N.; Huynh Nhu, T.; Duc Thuan, H.; Quoc Trung, V.; Minh Quan, P.; Manh Hung, T.; Dao Cuong, T. Glucose Uptake Stimulatory and PTP1B Inhibitory Activities of Pimarane Diterpenes from Orthosiphon stamineus Benth. Biomolecules $2019,9,859$.

75. Lee, H.-J.; Choi, Y.-J.; Park, S.-Y.; Kim, J.-Y.; Won, K.-C.; Son, J.-K.; Kim, Y.-W. Hexane Extract of Orthosiphon stamineus Induces Insulin Expression and Prevents Glucotoxicity in INS-1 Cells. Diabetes Metab. J. 2015, 39, 51-58. [CrossRef] [PubMed]

76. Stanford, K.I.; Goodyear, L.J. Exercise and type 2 diabetes: Molecular mechanisms regulating glucose uptake in skeletal muscle. Adv. Physiol. Educ. 2014, 38, 308-314. [CrossRef]

77. Khattak, M.M.A.K.; Taher, M.; Ichwan, S.J.A.; Azahari, N. Selected Herbal Extracts Improve Diabetes Associated Factors in 3T3-L1 Adipocytes. Procedia-Soc. Behav. Sci. 2013, 91, 357-375. [CrossRef] 
78. Azahari, N.; Khattak, M.M.A.K.; Taher, M.; Ichwan, S.J.A. Herbal extracts exhibit anti-diabetic activities in 3T3-L1 adipocytes model. Prog. Nutr. 2015, 17, 301-310.

79. Hatting, M.; Tavares, C.D.J.; Sharabi, K.; Rines, A.K.; Puigserver, P. Insulin regulation of gluconeogenesis. Ann. N. Y. Acad. Sci. 2018, 1411, 21-35. [CrossRef]

80. Zhang, X.; Yang, S.; Chen, J.; Su, Z. Unraveling the Regulation of Hepatic Gluconeogenesis. Front. Endocrinol. 2018, 9, 802. [CrossRef]

81. Ostergaard, L.; Frandsen, C.S.; Madsbad, S. Treatment potential of the GLP-1 receptor agonists in type 2 diabetes mellitus: A review. Expert Rev. Clin. Pharm. 2016, 9, 241-265. [CrossRef]

82. Parsamanesh, N.; Moossavi, M.; Bahrami, A.; Butler, A.E.; Sahebkar, A. Therapeutic potential of curcumin in diabetic complications. Pharm. Res. 2018, 136, 181-193. [CrossRef] [PubMed]

83. Liu, G.J.; Huang, R.G.; Zheng, X.Z.; Chen, J.H.; Li, Y.T. Study on the protective effect of Kidney tea on kidney of diabetic rats and its mechanism. Chin. J. Integr. Tradit. West. Nephrol. 2007, 8, 32-34.

84. Pariyani, R.; Ismail, I.S.; Azam, A.A.; Abas, F.; Shaari, K.; Sulaiman, M.R. Phytochemical Screening and Acute Oral Toxicity Study of Java Tea Leaf Extracts. Biomed Res. Int. 2015, 2015, 742420. [CrossRef]

85. Han, C.J.; Hussin, A.H.; Ismail, S. Toxicity study of Orthosiphon stamineus Benth (Misai Kucing) on Sprague Dawley rats. Trop. Biomed. 2008, 25, 9-16.

86. Mohamed, E.A.H.; Lim, C.P.; Ebrika, O.S.; Asmawi, M.Z.; Sadikun, A.; Yam, M.F. Toxicity evaluation of a standardised 50\% ethanol extract of Orthosiphon stamineus. J. Ethnopharmacol. 2011, 133, 358-363. [CrossRef]

87. Muhammad, H.; Sulaiman, S.A.; Ismail, Z.; Paumgartten, F.J.R. Study on the developmental toxicity of a standardized extract of in rats Orthosiphon stamineus. Rev. Bras. Farmacogn. 2013, 23, 513-520. [CrossRef]

88. Muhammad, H.; Gomes-Carneiro, M.R.; Poça, K.S.; De-Oliveira, A.C.A.X.; Afzan, A.; Sulaiman, S.A.; Ismail, Z.; Paumgartten, F.J.R. Evaluation of the genotoxicity of Orthosiphon stamineus aqueous extract. J. Ethnopharmacol. 2011, 133, 647-653. [CrossRef]

89. Li, J.Y.; Kang, L.Q. Research Progress in Exploitation and Utilization of Clerodendranthus spicatus. Acta Agric. Jiangxi 2010, 22, 99-104.

90. Song, L.Q.; Pei, C.P.; Song, Y.X. Clinical Study on the Treatment of Diabetic Nephropathy with Cordyceps Sinensis and Kidney Tea Decoction. Inf. Tradit. Chin. Med. 2009, 26, 38-39.

91. Song, L.Q.; Jin, L.; Song, Y. The Clinical Study of the Effect of Diabetic Nephropathy Treated by Chongcao Shencha Capsule. Chin. Arch. Tradit. Chin. Med. 2009, 27, 679-681.

92. Yu, S. Effects of Chongcao Shencha Capsule on Expression of the ECM and TIMP-1mRNA in Rat Glomerulosclerosis. Doctoral Thesis, Heilongjiang University of Chinese Medicine, Harbin, China, 2008.

93. $\mathrm{Xu}, \mathrm{Y}$. The Experimental Study and Clinical Observation on the Effects of Chongcaoshencha Prescription Inflencing Early Changes of Chronic Renal Failure. Doctoral Thesis, Heilongjiang University of Chinese Medicine, Harbin, China, 2007.

94. Vinothiya, K.; Ashokkumar, N. Modulatory effect of vanillic acid on antioxidant status in high fat diet-induced changes in diabetic hypertensive rats. Biomed Pharm. 2017, 87, 640-652. [CrossRef]

95. Song, Y.; Wu, T.; Yang, Q.; Chen, X.; Wang, M.; Wang, Y.; Peng, X.; Ou, S. Ferulic acid alleviates the symptoms of diabetes in obese rats. J. Funct. Foods 2014, 9, 141-147. [CrossRef]

96. Gandhi, G.R.; Ignacimuthu, S.; Paulraj, M.G.; Sasikumar, P. Antihyperglycemic activity and antidiabetic effect of methyl caffeate isolated from Solanum toroum Swartz. fruit in streptozotocin induced diabetic rats. Eur. J. Pharm. 2011, 670, 623-631. [CrossRef] [PubMed]

97. Tang, H.; Ma, F.; Zhao, D.; Xue, Z. Exploring the effect of salvianolic acid C on $\alpha$-glucosidase: Inhibition kinetics, interaction mechanism and molecular modelling methods. Process Biochem. 2019, 78, 178-188. [CrossRef]

98. Ngo, Y.L.; Lau, C.H.; Chua, L.S. Review on rosmarinic acid extraction, fractionation and its anti-diabetic potential. Food Chem. Toxicol. 2018, 121, 687-700. [CrossRef] [PubMed]

99. Mushtaq, N.; Schmatz, R.; Ahmed, M.; Pereira, L.B.; da Costa, P.; Reichert, K.P.; Dalenogare, D.; Pelinson, L.P.; Vieira, J.M.; Stefanello, N.; et al. Protective effect of rosmarinic acid against oxidative stress biomarkers in liver and kidney of strepotozotocininduced diabetic rats. J. Physiol. Biochem. 2015, 71, 743-751. [CrossRef] [PubMed]

100. Ou, J.; Huang, J.; Zhao, D.; Du, B.; Wang, M. Protective effect of rosmarinic acid and carnosic acid against streptozotocin-induced oxidation, glycation, inflammation and microbiota imbalance in diabetic rats. Food Funct. 2018, 9, 851-860. [CrossRef]

101. Wen, Y.J.; Yin, M.C. The anti-inflammatory and anti-glycative effects of rosmarinic acid in the livers of type 1 diabetic mice. Biomedicine 2017, 7, 37-41. [CrossRef]

102. Mahesh, R.; Sachinkumar, T.; Swati, K. Antiobesity, antihyperlipidemic and antidiabetic agents of protocatechuic acid in high fatty diet along with alloxan induced diabetes. Int. J. Pharm. Sci. Res. 2019, 10, 1742-1746.

103. Harini, R.; Pugalendi, K.V. Antioxidant and antihyperlipidaemic activity of protocatechuic acid on streptozotocindiabetic rats. Redox Rep. 2013, 15, 71-80. [CrossRef]

104. Runtuwene, J.; Cheng, K.C.; Asakawa, A.; Amitani, H.; Amitani, M.; Morinaga, A.; Takimoto, Y.; Kairupan, B.H.; Inui, A. Rosmarinic acid ameliorates hyperglycemia and insulin sensitivity in diabetic rats, potentially by modulating the expression of PEPCK and GLUT4. Drug Des. Devel. 2016, 10, 2193-2202.

105. Unger, J.R.; Parkin, C.G. Glucagon-like peptide-1 (GLP-1) receptor agonists: Differentiating the new medications. Diabetes 2011, 2, 29-39. [CrossRef] 
106. Ramalingam, S.; Karuppiah, M.; Thiruppathi, M. Antihyperglycaemic potential of rosmarinic acid attenuates glycoprotein moiety in high-fat diet and streptozotocin-induced diabetic rats. All Life 2020, 13, 120-130. [CrossRef]

107. Jiang, W.L.; Xu, Y.; Zhang, S.P.; Hou, J.; Zhu, H.B. Effect of rosmarinic acid on experimental diabetic nephropathy. Basic Clin. Pharm. Toxicol. 2012, 110, 390-395. [CrossRef]

108. Bhattacharjee, N.; Dua, T.K.; Khanra, R.; Joardar, S.; Nandy, A.; Saha, A.; de Feo, V.; Dewanjee, S. Protocatechuic Acid, a Phenolic from Sansevieria roxburghiana Leaves, Suppresses Diabetic Cardiomyopathy via Stimulating Glucose Metabolism, Ameliorating Oxidative Stress, and Inhibiting Inflammation. Front. Pharmacol. 2017, 8, 251. [CrossRef]

109. Jin, C.J.; Yu, S.H.; Wang, X.M.; Woo, S.J.; Park, H.J.; Lee, H.C.; Choi, S.H.; Kim, K.M.; Kim, J.H.; Park, K.S.; et al. The effect of lithospermic acid, an antioxidant, on development of diabetic retinopathy in spontaneously obese diabetic rats. PLoS ONE 2014, 9, e98232

110. Pei, Y.; Dong, X.; Tang, X.Y.; He, A.H.; Yang, H.; Zhou, H.; Zou, J.Z.; Li, H.N. Influence of Caffeic Acid on blood glucose concentration in rats with type 2 diabetes mellitus. China Mod. Med. 2018, 25, 16-18.

111. Sotnikova, R.; Okruhlicova, L.; Vlkovicova, J.; Navarova, J.; Gajdacova, B.; Pivackova, L.; Fialova, S.; Krenek, P. Rosmarinic acid administration attenuates diabetes-induced vascular dysfunction of the rat aorta. J. Pharm. Pharm. 2013, 65, 713-723. [CrossRef] [PubMed]

112. Yang, Z.; Huang, W.; Zhang, J.; Xie, M.; Wang, X. Baicalein improves glucose metabolism in insulin resistant HepG2 cells. Eur. J. Pharmacol. 2019, 854, 187-193. [CrossRef]

113. Sarkar, P.; Nath, K.; Banu, S. Modulatory effect of baicalein on gene expression and activity of antioxidant enzymes in streptozotocin-nicotinamide induced diabetic rats. Braz. J. Pharm. Sci. 2019, 55, e18201. [CrossRef]

114. Annadurai, T.; Muralidharan, A.R.; Joseph, T.; Hsu, M.J.; Thomas, P.A.; Geraldine, P. Antihyperglycemic and antioxidant effects of a flavanone, naringenin, in streptozotocin-nicotinamide-induced experimental diabetic rats. J. Physiol. Biochem. 2012, 68, 307-318. [CrossRef]

115. Jung, H.A.; Ali, M.Y.; Bhakta, H.K.; Min, B.S.; Choi, J.S. Prunin is a highly potent flavonoid from Prunus davidiana stems that inhibits protein tyrosine phosphatase 1B and stimulates glucose uptake in insulin-resistant HepG2 cells. Arch. Pharm. Res. 2017, 40, 37-48. [CrossRef] [PubMed]

116. Huang, X.L.; He, Y.; Ji, L.L.; Wang, K.Y.; Wang, Y.L.; Chen, E.F.; Geng, Y.; OuYang, P.; Lai, W.M. Hepatoprotective potential of isoquercitrin against type 2 diabetes-induced hepatic injury in rats. Oncotarget 2017, 8, 101545-101559. [CrossRef] [PubMed]

117. Den Hartogh, D.J.; Tsiani, E. Antidiabetic Properties of Naringenin: A Citrus Fruit Polyphenol. Biomolecules 2019, 9, 99. [CrossRef] [PubMed]

118. Singh, A.K.; Raj, V.; Keshari, A.K.; Rai, A.; Kumar, P.; Rawat, A.; Maity, B.; Kumar, D.; Prakash, A.; De, A.; et al. Isolated mangiferin and naringenin exert antidiabetic effect via PPARgamma/GLUT4 dual agonistic action with strong metabolic regulation. Chem. Biol. Interact. 2018, 280, 33-44. [CrossRef] [PubMed]

119. Priscilla, D.H.; Jayakumar, M.; Thirumurugan, K. Flavanone naringenin: An effective antihyperglycemic and antihyperlipidemic nutraceutical agent on high fat diet fed streptozotocin induced type 2 diabetic rats. J. Funct. Foods 2015, 14, 363-373. [CrossRef]

120. Sirovina, D.; Orsolic, N.; Gregorovic, G.; Koncic, M.Z. Naringenin ameliorates pathological changes in liver and kidney of diabetic mice: A preliminary study. Arh. Hig. Rada. Toksikol. 2016, 67, 19-24. [CrossRef] [PubMed]

121. Roy, S.; Ahmed, F.; Banerjee, S.; Saha, U. Naringenin ameliorates streptozotocin-induced diabetic rat renal impairment by downregulation of TGF- $\beta 1$ and IL-1 via modulation of oxidative stress correlates with decreased apoptotic events. Pharm. Biol. 2016, 54, 1616-1627. [CrossRef]

122. Ahad, A.; Mujeeb, M.; Ahsan, H.; Siddiqui, W.A. Prophylactic effect of baicalein against renal dysfunction in type 2 diabetic rats Biochimie 2014, 106, 101-110. [CrossRef]

123. Tsai, S.J.; Huang, C.S.; Mong, M.C.; Kam, W.Y.; Huang, H.Y.; Yin, M.C. Anti-inflammatory and antifibrotic effects of naringenin in diabetic mice. J. Agric. Food Chem 2012, 60, 514-521. [CrossRef]

124. Singh, P.; Bansal, S.; Kuhad, A.; Kumar, A.; Chopra, K. Naringenin ameliorates diabetic neuropathic pain by modulation of oxidative-nitrosative stress, cytokines and MMP-9 levels. Food Funct. 2020, 11, 4548-4560. [CrossRef]

125. Zaidun, N.H.; Sahema, Z.C.T.; Mardiana, A.A.; Santhana, R.L.; Latiff, A.A.; Syed Ahmad Fuad, S.B. Effects of naringenin on vascular changes in prolonged hyperglycaemia in fructose-STZ diabetic rat model. Drug Discov. Ther. 2019, 13, $212-221$. [CrossRef]

126. Al-Dosari, D.I.; Ahmed, M.M.; Al-Rejaie, S.S.; Alhomida, A.S.; Ola, M.S. Flavonoid Naringenin Attenuates Oxidative Stress, Apoptosis and Improves Neurotrophic Effects in the Diabetic Rat Retina. Nutrients 2017, 9, 1161. [CrossRef]

127. Sun, W.; Sun, J.; Zhang, B.; Xing, Y.; Yu, X.; Li, X.; Xiu, Z.; Dong, Y. Baicalein improves insulin resistance via regulating SOCS3 and enhances the effect of acarbose on diabetes prevention. J. Funct. Foods 2017, 37, 339-353. [CrossRef]

128. Wei, X.F.; Lin, S.B.; Xiong, H.P.; Yang, Y.; Zhou, Q.; Xu, J. The Influence of Baicalein on Islet Function in Diabetic Rats. Chin. J. Integr. Med. Cardio-Cerebrovasc. Dis. 2019, 17, 2933-2935.

129. Wen, L.; Chen, L.; Sui, Y.X.; Duan, Q.R.; Wei, L.J.; Zhou, Q.; Peng, H.M.; Zhang, Z. Naringenin ameliorates kidney injury by inhibiting TGF- $\beta 1$ /smad signaling pathway in diabetic nephropathy rats. Basic Clin. Med. 2016, 36, 896-901.

130. Wang, J.; Zhao, J.; Yan, Y.; Liu, D.; Wang, C.; Wang, H. Inhibition of glycosidase by ursolic acid: In vitro, in vivo and in silico study. J. Sci. Food Agric. 2020, 100, 986-994. [CrossRef] 
131. Ding, H.; Hu, X.; Xu, X.; Zhang, G.; Gong, D. Inhibitory mechanism of two allosteric inhibitors, oleanolic acid and ursolic acid on alpha-glucosidase. Int. J. Biol. Macromol. 2018, 107, 1844-1855. [CrossRef] [PubMed]

132. Ziwei, W.; Na, Z.; Shengbo, F.; Xin, Z. Effect of ursolic acid on obesity-induced insulin resistance in rat liver. Trop. J. Pharm. Res. 2018, 17, 837-842. [CrossRef]

133. Wang, X.; Liu, R.; Zhang, W.; Zhang, X.; Liao, N.; Wang, Z.; Li, W.; Qin, X.; Hai, C. Oleanolic acid improves hepatic insulin resistance via antioxidant, hypolipidemic and anti-inflammatory effects. Mol. Cell. Endocrinol. 2013, 376, 70-80. [CrossRef]

134. Manna, P.; Ghosh, J.; Das, J.; Sil, P.C. Streptozotocin induced activation of oxidative stress responsive splenic cell signaling pathways: Protective role of arjunolic acid. Toxicol. Appl. Pharm. 2010, 244, 114-129. [CrossRef]

135. Bacanli, M.; Aydin, S.; Anlar, H.G.; Cal, T.; Undeger Bucurgat, U.; Ari, N.; Basaran, A.A.; Basaran, N. Protective Effects of Ursolic Acid in the Kidneys of Diabetic Rats. Turk. J. Pharm. Sci. 2018, 15, 166-170. [CrossRef] [PubMed]

136. Wu, J.B.; Kuo, Y.H.; Lin, C.H.; Ho, H.Y.; Shih, C.C. Tormentic acid, a major component of suspension cells of Eriobotrya japonica, suppresses high-fat diet-induced diabetes and hyperlipidemia by glucose transporter 4 and AMP-activated protein kinase phosphorylation. J. Agric. Food Chem. 2014, 62, 10717-10726. [CrossRef]

137. Manna, P.; Sil, P.C. Impaired redox signaling and mitochondrial uncoupling contributes vascular inflammation and cardiac dysfunction in type 1 diabetes: Protective role of arjunolic acid. Biochimie 2012, 94, 786-797. [CrossRef] [PubMed]

138. Flávia, A.S.; Julyanne, T.F.; Bruno, R.A.; Tiago, S.M.; Armenio, A.C.A.S.; Gerly, A.C.B.; Mariana, H.C.; Vietla, S.R. Antihyperglycemic and hypolipidemic effects of $\alpha, \beta$-amyrin, a triterpenoid mixture from Protium heptaphyllum in mice. Lipids Health Dis. 2012, 11, 1-8.

139. Liu, J.; Wang, X.; Chen, Y.-P.; Mao, L.-F.; Shang, J.; Sun, H.-B.; Zhang, L.-Y. Maslinic acid modulates glycogen metabolism by enhancing the insulin signaling pathway and inhibiting glycogen phosphorylase. Chin. J. Nat. Med. 2014, 12, 259-265. [CrossRef]

140. Birgani, G.A.; Ahangarpour, A.; Khorsandi, L.; Moghaddam, H.F. Anti-diabetic effect of betulinic acid on streptozotocinnicotinamide induced diabetic male mouse model. Braz. J. Pharm. Sci. 2018, 54, e17171. [CrossRef]

141. Manna, P.; Sil, P.C. Arjunolic acid: Beneficial role in type 1 diabetes and its associated organ pathophysiology. Free Radic. Res. 2012, 46, 815-830. [CrossRef]

142. Ding, H.; Ni, M.; Zhang, G.; Liao, Y.; Hu, X.; Zhang, Y.; Gong, D. The inhibition of oleanolic acid on protein non-enzymatic glycation. LWT 2020, 125, 109253. [CrossRef]

143. Ahangarpour, A.; Oroojan, A.A.; Khorsandi, L.; Shabani, R.; Mojaddami, S. Preventive effects of betulinic acid on streptozotocinnicotinamide induced diabetic nephropathy in male mouse. J. Nephropathol. 2016, 5, 128-133. [CrossRef]

144. Xu, H.L.; Wang, X.T.; Cheng, Y.; Zhao, J.G.; Zhou, Y.J.; Yang, J.J.; Qi, M.Y. Ursolic acid improves diabetic nephropathy via suppression of oxidative stress and inflammation in streptozotocin-induced rats. Biomed. Pharm. 2018, 105, 915-921. [CrossRef]

145. Mkhwanazi, B.N.; Serumula, M.R.; Myburg, R.B.; van Heerden, F.R.; Musabayane, C.T. Antioxidant effects of maslinic acid in livers, hearts and kidneys of streptozotocin-induced diabetic rats: Effects on kidney function. Ren Fail 2014, 36, $419-431$. [CrossRef] [PubMed]

146. Ling, C.; Jinping, L.; Xia, L.; Renyong, Y. Ursolic Acid Provides Kidney Protection in Diabetic Rats. Curr. Ther. Res. 2013, 75, 59-63. [CrossRef]

147. Zhou, Y.; Li, J.S.; Zhang, X.; Wu, Y.J.; Huang, K.; Zheng, L. Ursolic acid inhibits early lesions of diabetic nephropathy. Int. J. Mol. Med. 2010, 26, 565-570. [PubMed]

148. Mkhwanazi, B.N.; van Heerden, F.R.; Mavondo, G.A.; Mabandla, M.V.; Musabayane, C.T. Triterpene derivative improves the renal function of streptozotocin-induced diabetic rats: A follow-up study on maslinic acid. Ren Fail 2019, 41, 547-554. [CrossRef]

149. Wang, X.T.; Gong, Y.; Zhou, B.; Yang, J.J.; Cheng, Y.; Zhao, J.G.; Qi, M.Y. Ursolic acid ameliorates oxidative stress, inflammation and fibrosis in diabetic cardiomyopathy rats. Biomed Pharm. 2018, 97, 1461-1467. [CrossRef]

150. Chen, J.; Wu, Y.X.; Lv, H.; Jian, T.Y.; Ding, X.Q.; Li, J.W.; Liu, Y.; Ren, B.R. Study on in vitro activities of triterpene acids from leaf of Eriobotrya japonica against diabetes and its complications. J. Plant Resour. Environ. 2020, 29, 78-80.

151. Xu, L.; Wang, C. Research Progress and Prospect of Oleanolic Acid in Treatment of Diabetes. Chin. J. Exp. Tradit. Med. Formulae 2018, 24, 228-234.

152. Zhang, M.F.; Shen, Y.Q. Research Advances in Pharmacological Effects of oleanolic Acid in HyPoglycemia and Antidiabetic Complications. Anti-Infect. Pharm. 2015, 12, 801-806.

153. Joshi, T.; Singh, A.K.; Haratipour, P.; Sah, A.N.; Pandey, A.K.; Naseri, R.; Juyal, V.; Farzaei, M.H. Targeting AMPK signaling pathway by natural products for treatment of diabetes mellitus and its complications. J. Cell Physiol. 2019, 234, 17212-17231. [CrossRef] [PubMed]

154. Feng, J.; Lu, S.; Ou, B.; Liu, Q.; Dai, J.; Ji, C.; Zhou, H.; Huang, H.; Ma, Y. The Role of JNk Signaling Pathway in Obesity-Driven Insulin Resistance. Diabetes Metab. Syndr. Obes. 2020, 13, 1399-1406. [CrossRef]

155. Dua, T.K.; Joardar, S.; Chakraborty, P.; Bhowmick, S.; Saha, A.; de Feo, V.; Dewanjee, S. Myricitrin, a Glycosyloxyflavone in Myrica esculenta Bark Ameliorates Diabetic Nephropathy via Improving Glycemic Status, Reducing Oxidative Stress, and Suppressing Inflammation. Molecules 2021, 26, 258. [CrossRef] [PubMed]

156. Xie, L.; Lan, F.; Xiang, C.; Shi, W.; Xie, Y.; Tao, Z. Clinical observation on treating 63 cases of chronic glomerulonephritis with Shencha. Guangxi J. Tradit. Chin. Med. 2013, 36, 29-31.

157. Chen, H.; Zhang, M. Structure and Health Effects of Natural Products on Diabetes Mellitus; Springer: Singapore, 2021. 